\title{
A Tale of Two Bazaar Economies: An Input-output Analysis for Germany and Italy \\ Emanuele Breda
}

Banca d'Italia, Economic Research and International Relations; emanuele.breda@bancaditalia.it.

Rita Cappariello

Banca d'Italia, Economic Research and International Relations; rita.cappariello@bancaditalia.it.

This paper ${ }^{1}$ evaluates the extent of production internationalisation in Italy and Germany between 1995 and 2007. The analysis is based on a broad set of international outsourcing indicators to which we have added a new indicator to take account also of the import content of domestic inputs: the direct and indirect import content of production. In 2007, both countries showed a similar intensity of international off-shoring, although Italian manufacturing firms showed a slightly higher rate. From a dynamic viewpoint, both economies spurred substantial growth in off-shoring in 1995-2000, although the growth was stronger in Germany, where at least manufacturing started from a lower level. In 2001-2003, off-shoring levels stagnated in both economies, although growth quickly resumed in 2004-2007, suggesting a shift in the strategic direction and the reorganization of production by Italian firms. The new challenges posed by globalization, the widespread take-up of information and communication technologies, and the adoption of the euro have induced the most dynamic Italian firms to rethink their organizational set-up, including the degree of vertical specialisation.

International outsourcing, Input-output Tables

\section{Introduction}

Starting with evidence of a sharp decline in domestic value added in manufacturing, in 2003, Sinn used the expression "bazaar economy" to define the role played by the international fragmentation of production in the German economy. International relocation of production was, indeed, particularly intense in that country, especially in the second half of the 1990s, just after the integration of the neighbouring Eastern European countries. ${ }^{2}$

In the economic literature and debate there are mixed feelings about internationalisation. Some maintain that it destroys jobs at home and, more generally, weakens the value-added base of domestic production. Others point out that it increases the firms' competitiveness and may therefore have, on balance, a positive effect on domestic value added and employment. As a matter of fact, in Germany the "bazaar economy" argument has been widely debated.

\footnotetext{
${ }^{1}$ We wish to thank Alessandra De Michele, Stefano Federico, Jean Imbs, Marco Magnani, Luigi Federico Signorini, and Roberto Tedeschi for their valuable advice, the two anonymous referees, and the seminar participants at the University of Lausanne, the Eurosystem seminar Competitiveness and external imbalances in the euro area countries (ECB, Frankfurt am Main, 25-26 March 2009), the meeting of the Working Party on International Trade in Goods and Trade in Services Statistics (OECD, Paris, 4-6 October 2010) and the $2^{\text {nd }}$ EPI annual Conference (Parma, 20-21 June 2011). The usual disclaimer applies. The views expressed herein are those of the authors and not necessarily those of the Bank of Italy. This paper is an update of the Bank of Italy Occasional papers 79, December 2010.

${ }^{2}$ Companies can use two different forms to relocate production abroad: international outsourcing and offshoring. The former consists of the contracting-out of some of the intermediate production phases and the purchasing of components parts from foreign suppliers. The second sees domestic firms set up plants abroad to produce their intermediate products. Both forms share some of the same microeconomic implications, and the paper includes both concepts using the two definitions interchangeably.
} 
German firms moved part of their production abroad mainly to obtain labour cost reductions ${ }^{3}$ and, in so doing, narrow their competitive disadvantages and boost their exports, reducing at the same time the share of domestically-produced value added:

Although German industrial production increased by fifteen percent between 1995 and 2003, real value added of German industry increased by only 5 percent in the same period. [...] Industrial employment decreased by ten percent in the same period without new jobs having been created to offset these losses. [...] Competitiveness can no longer be measured in terms of German exports. [...] Germany is becoming a bazaar economy that sells the world economical, highquality products that were not produced in the country. (Sinn, 2003).

Other authors have different opinions about this phenomenon: Belke et al. (2007) argue that traditional measures of trade openness usually overstate the actual degree of openness and, since both gross value of exports and value added in export production increased between 1997 and 2001, German firms actually gained from internationalisation. Danninger and Joutz (2007) show that German export market share has increased since 2000 not only because of international outsourcing, but also thanks to trade relationships with fast growing countries.

All the studies that evaluate the consequences of internationalisation using data at industry level rely on a large and quite differentiated set of indicators of international outsourcing. Thus, it does not exist a unique and univocally accepted measure of this phenomenon at an aggregate macro level.

Feenstra and Hanson (1996) estimate the share of imported inputs on total purchases of intermediate products in order to measure the increase of international outsourcing between 1972 and 1990 for the United States. Hummels et al. (1998, 2001) find an increase in outsourcing for some OECD countries during the 1980s by measuring the import content of exports. A broader indicator, which considers both direct and indirect import content of exports, is calculated by Chen et al. (2005) to measure the same phenomenon for a group of OECD countries. In Egger and Egger (2003) a measure of direct import content of production is used to calculate the average annual change of international outsourcing between 1990 and 1997 for a number of European countries. ${ }^{4}$

Almost all the indicators used in these studies are calculated by using information on intermediate imported inputs from input-output tables, which allow to split the output of each sector into two parts, the first consisting of inputs to the other sectors, the second consisting of goods which satisfy the final demand. These indicators provide a quite exhaustive measure of the phenomenon, since they do not make a distinction between the different channels of internationalisation chosen by the firms, including both types of intermediate inputs: parts and

\footnotetext{
${ }^{3}$ Shipping costs also play a role, although not always in an obvious way. According to Baldwin and Venables (2010), changes in shipping costs could affect the relocation strategies of production stages between high and low labour cost countries in a non-linear fashion because of the technological relationship between stages of production.

${ }^{4}$ Among the studies that use such indicators to evaluate the impact of outsourcing on productivity and employment at sectoral level, Amiti and Wei (2005a and 2005b) found that off-shoring had a positive effect on productivity and job growth in the UK and the US, respectively, especially in services. Egger and Egger (2006), however, found that the relation between off-shoring and productivity for the manufacturing industry in twelve EU countries has a positive impact only in the longer term. Other studies based on survey data use ad hoc criteria to identify internationalised firms. Bugamelli et al. (2008) find a positive correlation between value-added (or labour productivity) growth and internationalisation using a panel of Italian manufacturing firms for the 2000-06 period, only when a very broad definition of outsourcing is adopted. Barba Navaretti and Castellani (2004) found no evidence of international outsourcing and FDI having a negative effect on the domestic employment level for a sample of Italian firms. In terms of the impact of internationalisation on the skills structure of employment, Diehl (1999) and Jäckle (2006) found evidence that outsourcing abroad actually increased the intensity of domestic skill, whereas Marin $(2004,2006)$ found it had the opposite effect on German and Austrian multinational enterprises.
} 
components, and goods produced by subcontractors or affiliates abroad. ${ }^{5}$ Moreover, the use of indicators based on input-output tables allow to avoid an arbitrary dichotomy between intermediate inputs and other categories of goods, which is very common in trade statistics. Alternatively, the amount of intermediate imported inputs is inferred from trade data assuming that the share of imported intermediate goods and services on total inputs is the same in every industry of the economy. This methodology is used in Feenstra and Hanson (1996) and employed in many other studies (Amiti and Wei 2005a and 2005b).

In this paper we utilise the input-output tables of imported products compiled by the national statistical institutes, which are available up to 2007 for both Germany and Italy. ${ }^{6}$ This allows us to outline the pattern of fragmentation of production for two of the main economies in the Euro area also for more recent years without resorting to the restrictive import proportionality assumption' of Feenstra and Hanson. ${ }^{7}$ Although other studies have analysed the development of international outsourcing in the Italian economy by using the same data (Bracci 2006, Falzoni and Tajoli 2007, Daveri and Jona-Lasinio 2008), none of these studies focuses on methodological issues regarding the different indicators utilised to proxy international outsourcing and their meaning, or on a cross-country comparison. ${ }^{8}$ Moreover, we propose the direct and indirect import content of domestic production as a new indicator for international outsourcing. Since this indicator also takes into account the value of inputs which are indirectly used in the production of domestic goods, we believe that this measure can be more useful than other standard indicators for a synthetic evaluation of the macroeconomic consequences of international outsourcing.

The analysis provides a statistical framework to compare the development of vertical specialisation in the production of the two countries, but it does not provide evidence on the direction of causality between firms' choice of outsourcing and productivity or competitiveness at a macro level. An approach based on micro data or on FDI seems to be more suitable to this scope, since it allows to better control for the firms' choices to relocate the production abroad.

Our analysis confirms that the development of international outsourcing was substantial in both countries, with a steady growth between 1995 and 2000, a stagnation (or slight reduction) in the early years of the past decade and a fast growth in the last years analysed (2004-2007). Therefore, the marked increase in international outsourcing observed between 1995 and $2000^{9}$ was not just biased by the exceptional cyclical peak reached by international trade in 2000, and reflected instead a trend towards more internationally integrated production processes. Moreover, the evidence of a higher increase in international outsourcing for Germany with respect to Italy, provided by all the indicators, is due to both a stronger growth

\footnotetext{
${ }^{5}$ Moreover, these measurements do not take account of the international outsourcing of the entire production and distribution processes (export platforms) to foreign subsidiaries, as this case implies neither the flows of goods and services across home country borders, nor a change in the import content of domestic production.

${ }^{6}$ The German and the Italian economy are fairly similar in size and structure, making it reasonable to compare the international outsourcing levels between the two countries. In contrast, a comparison with smaller economies appears less appropriate because of their higher trade openness (OECD, 2007).

${ }^{7}$ As for the Italian economy, Daveri and Jona-Lasinio (2008) show that quantifying intermediate imported inputs according to the Feenstra-Hanson methodology rather than using direct data on intermediate imported inputs leads to a significant downward bias of the most common indicators for international outsourcing, i.e. the ratio between intermediate imported inputs and total inputs.

${ }^{8}$ In these studies only the two main indicators for international outsourcing are constructed, both based on the ratio between intermediate imported inputs and total inputs. Bracci (2006) shows the sectoral development of internationalisation in Italy between 1995 and 2003. Falzoni and Tajoli (2007) use the same data and indicators to verify the relationship between outsourcing and employment, in terms of level and skill composition. Adopting the same approach, Daveri and Jona-Lasinio (2008) are interested in studying the link between outsourcing and productivity.

${ }^{9}$ See Breda et al. (2009).
} 
of internationalisation within sectors and a more marked shift of the German economy towards more fragmented international sectors.

Our comparison by a large set of outsourcing indices, each of which captures a different aspect of the phenomenon, provides evidence that in 2007, the last year in our analysis, the level of international outsourcing is comparable between the two countries. Considering manufacturing sectors only, Italian firms seem to be slightly more internationalised than German firms: in 2007 the import content of production amounted to 31.1 per cent in Italy and to 29.5 per cent in Germany, despite the higher share of low-tech sectors, which are the least internationally fragmented, in the first country.

The paper is organised as follows: in the next section we present some indicators commonly used in literature to measure the international fragmentation of production and propose our indicator measuring the direct and indirect import content of production. By considering their definition and construction, we evaluate their respective ability to capture different aspects of the phenomenon. In section 3, the evolution of international outsourcing from 1995 to 2007 for Italy and Germany is analysed at aggregate and industry level. A comparison of the indices and a shift-share analysis to decompose the variance of the indices into different components are presented in section 4 to provide some hints on international outsourcing patterns in different sectors. Finally, section 5 resumes the main results.

\section{Concepts and indicators}

The literature uses a wide variety of international outsourcing measures, therefore it is necessary to define and describe the properties of the set of indicators used in the paper to measure the extent of international outsourcing in Italy and Germany.

The first group of indicators focuses on the weight of imported inputs on total inputs. Because of its design, this class of measures provides information on the firms' strategies approaches to the acquisition of intermediate inputs in external and/or domestic markets. This group of indicators therefore provides a direct measure of the industries' international activity, i.e. firms' international outsourcing net of the degree of 'vertical integration' found in the production process in each industry (the weight of physical inputs, regardless of their origin, on total production). Feenstra and Hanson (1996) use this index to measure international outsourcing in the US manufacturing sector from 1972 to 1990. The same approach is adopted by the European Economic Advisory Group (2005) to measure outsourcing in a set of European countries from 1995 to 2000.

Similarly, Feenstra and Hanson (1996, 1999) propose two slightly different indicators for international outsourcing to evaluate its effects on US wages: a broad index, the ratio between imported inputs from all sectors to total (domestic and imported) inputs employed in each industry, ${ }^{10}$ and a narrow index, which restricts the scope to those inputs that are purchased from the same industry as that in which the good is being produced, i.e. the standard intraindustry trade measure. These indices are used by Bracci (2006), Falzoni and Tajoli (2007) and Daveri and Jona-Lasinio (2008) to measure the increase of international outsourcing for the Italian manufacturing sector between 1995 and 2003.

The general formula to calculate the broad index is:

$$
I I T I \_ \text {broad }=\sum_{i=1}^{n}\left[\left(\sum_{j=1}^{J} \frac{m_{j i}}{m_{j i}+d_{j i}}\right)\left(\frac{m_{i}+d_{i}}{M+D}\right)\right]
$$

${ }^{10}$ As indicated earlier, Feenstra and Hanson (1999) derive data on imported inputs for each industry by assuming that any manufacturing employs imported inputs in the same proportion, whereas most of the quoted studies are based on input-output tables. 
with $m_{j i}$ and $d_{j i}$ corresponding respectively to imported and domestically-produced inputs from industry $j=1, \ldots, J$ used to produce output in industry $I=1, . ., n ; m_{i}$ and $d_{i}$ corresponding to total inputs, both domestic and imported, of industry $i ; M$ and $D$ to total inputs, both domestic and imported, of the economy. The term in the first brackets represents the weight of imported inputs on total inputs in sector $i$, whereas the IITI formula refers to the whole economy.

The formula to calculate the narrow index is:

$$
I I T I_{\text {narrow }}=\sum_{i=1}^{n}\left[\left(\frac{m_{i i}}{m_{i i}+d_{i i}}\right)\left(\frac{m_{i i}+d_{i i}}{M+D}\right)\right]
$$

with $m_{i i}$ and $d_{i i}$ corresponding respectively to imported and domestically-produced intraindustry inputs; $m_{i i}+d_{i i}$ to total intra-industry inputs of industry $i$; $M$ and $D$ to total intraindustry inputs of the whole economy.

The second class of indices refers to the import content of domestic production by measuring the imported intermediate inputs as a share of gross production. Unlike IITI indices, this group of indicators does not focus on the firms' choice between domestic and external input markets, but is intended to capture the firms' substitution of domestic production with foreign production phases. Since this measure of international outsourcing is sensitive to the degree of vertical integration, this class of indices is useful to evaluate the effects of international outsourcing on macroeconomic variables (employment, labour intensity skills, value added), although it is less reliable for comparing indices across industries. This measure was first introduced by Egger and Egger (2003) to calculate the average annual change of international outsourcing for eleven European countries in the 1990s. The index can be expressed as follows:

$$
I C P=\sum_{i=1}^{n}\left[\frac{\sum_{j=1}^{J} m_{j i}}{y_{i}} \cdot \frac{y_{i}}{Y}\right]
$$

with $y_{i}$ representing the gross output of industry $i$ and $Y$ the country gross output. The expression [3] shows that the aggregate ICP, expressed as a share of total output, is the output-weighted sum of each industry's import content.

Using this index as our starting point, the indicator we propose to use differs because it includes the value of the inputs indirectly used in the production of goods. We believe this measure to be more useful from a macroeconomic point of view. An imported input can indeed be used in a sector whose output is in turn employed in another sector, and then possibly in a third sector and so forth, until it is eventually included in a final good. In this case the measure of the import content of production would include both directly and indirectly imported inputs, the latter being defined as those already contained in domestic inputs.

The measure for the direct and indirect import content is as follows:

$$
D I I C P=\sum_{i=1}^{n}\left[\frac{\sum_{j=1}^{J}\left(m_{j i}+\sum_{k=1}^{K} a_{k j} d_{j i}\right)}{y_{i}} \cdot \frac{y_{i}}{Y}\right]
$$


where $0 \leq{ }_{m} a_{k j} \leq 1$ is a multiplicative coefficient of the imported input from sector $k$ that is embodied in the domestic production of sector $j$, and subsequently used as an input in industry $i\left(d_{j i}\right){ }^{11}$

Finally, a third class of proxies for vertical specialisation is the import content of exports. This measure was originally proposed by Hummels et al. (2001) to capture the situation of goods and services produced in multiple stages across different countries, with each country carrying out specific stages of the production sequence and then exporting the good-inprocess to the next country. This measure not only includes the value of imports directly contained in the exports, but also the value of inputs indirectly used in the production of the exported good, i.e. imported inputs embedded in domestic inputs. The index of vertical specialisation is a reliable proxy for measuring 'globalisation' because it is capable of capturing the production chains that link the different countries, whether as intermediatephase producers or exporters of final goods. Chen et al. (2005) use this index to calculate vertical specialisation for a series of OECD countries by using the latest input-output tables available for each. Two ECB studies (2005a and 2005b) adopt this approach in the debate on the structural changes of European economies. The same indicator is used in Breda et al. (2009) to estimate the pattern of international outsourcing for a set of European countries from 1995 to 2000. The formulas illustrated below describe the calculations to obtain the direct import content of exports (ICE) and the direct and indirect import content of exports (DIICE):

$$
I C E=\sum_{i=1}^{n}\left[\frac{\sum_{j=1}^{J} m_{j i}}{y_{i}} \cdot \frac{x_{i}}{X}\right]
$$

and

$$
D I I C E=\sum_{i=1}^{n}\left[\frac{\sum_{j=1}^{J}\left(m_{j i}+\sum_{k=1}^{K} a_{k j} d_{j i}\right)}{y_{i}} \cdot \frac{x_{i}}{X}\right]
$$

with $x_{i}$ the exports of industry $i=1, . ., n$ and $X$ the country total export. Examining [5] and [6], it can be noticed that ICE and DIICE are respectively the export share-weighted average of each industry's ICP and DIICP. Since export-intensive industries are more exposed to international competition and generally have a higher degree of international fragmentation of production, we expect to find higher values for the aggregate indicators based on exports than for those based on production.

According to the theoretical definitions, the IITI index should result in higher values than the ICP and DIICP indices, since the value of total inputs is always smaller than the value of total production or gross output. The relationship between the IITI and the ICE-DIICE indicators is less straightforward.

Finally, an index of international outsourcing made popular by some recent studies on the German economy is the share of domestic value-added on production:

$$
V A P=\sum_{i=1}^{n}\left[\frac{v_{i}}{y_{i}} \cdot \frac{y_{i}}{Y}\right]
$$

\footnotetext{
${ }^{11}$ See also the definition (A4) in the Appendix.
} 
with $v_{i}$ as value added of industry $i=1, . ., n$. Unlike the other indicators illustrated above, this indicator decreases as the degree of international outsourcing increases. The well-known definition of the German economy as a "bazaar economy" proposed by Sinn (2003) is due to the significant decrease shown by the German manufacturing industry in this index after 1995. However, whereas the IITI, ICP and ICE groups of indices are designed as direct measures of international outsourcing, the ability of the VAP index to capture industries' international activity is less straightforward. Nevertheless, the time pattern of the VAP index may be useful to detect changes in the degree of industries' international outsourcing.

\section{International outsourcing in Italy and Germany}

\subsection{The extent of internationalisation}

The indicators presented in this section are constructed on the basis of two sets of annual input-output tables released by Eurostat and Istat, respectively; each set contains information on domestically-produced inputs and imported inputs. ${ }^{12}$ All the indices presented are calculated based on the total purchase of non-energy products and market services, with energy products excluded to prevent their highly volatile prices influencing the results.

The analysis of international outsourcing in Italy and Germany refers to 1995, 2000 and 2007, using the two sub-periods to analyse the dynamics from 1995 to 2007. Table 1 and table 2 show the values of the international outsourcing indices in 1995, 2000 and 2007, for Italy and Germany, respectively at different levels of industry aggregation, i.e. the whole economy, total manufacturing, manufacturing divided into low, medium and high-tech industries ${ }^{13}$ and market services industries. ${ }^{14}$ The development of the IITI and the ICP indices for Italy and Germany is additionally illustrated for the whole economy, manufacturing and services in figure 1 , figure 2 and figure 3 , respectively. ${ }^{15}$

Table 1. Measures of international outsourcing in Italy

\footnotetext{
${ }^{12}$ For methodological issues see for Italy, Istat (2006) and, for Germany, Eurostat (2008) .

${ }^{13}$ This classification is an adaptation to 2-digit NACE codes of the classification by technological intensity adopted in Anderton (1999) and ECB (2005c). Low-tech products are: Food, beverages and tobacco; Textile products and clothing; Leather and leather products; Wood and wood products; Paper and paper products, printing and publishing; Non-metallic mineral products; Basic metals and metal products; Furniture and other manufactures. Medium-tech products are: Chemical products and man-made fibres; Rubber and plastic products; Mechanical machinery and equipment; Transport equipment. High-tech products are: Electrical equipment and precision instruments.

14 This paper defines "market services" as: transportation, trade, financial, renting and business services. Although other services (education, personal and health services etc.) also include a market component, we consider these sectors as scarcely involved in international fragmentation and trade.

${ }^{15}$ For Germany, the graphs do not include the 1996-1999 period, due to the lack of available data.
} 


\begin{tabular}{|c|c|c|c|c|c|c|c|}
\hline \multirow[b]{2}{*}{ Sectors } & \multicolumn{2}{|c|}{$\begin{array}{l}\text { Import content of } \\
\text { production }\end{array}$} & \multicolumn{2}{|c|}{$\begin{array}{l}\text { Import content of } \\
\text { exports }\end{array}$} & \multirow{2}{*}{$\begin{array}{c}\text { Imported } \\
\text { inputs on } \\
\text { Total } \\
\text { inputs } \\
\text { (IITI) }\end{array}$} & \multirow[b]{2}{*}{$\begin{array}{l}\text { Narrow } \\
\text { index }\end{array}$} & \multirow[b]{2}{*}{$\begin{array}{c}\text { Value } \\
\text { added on } \\
\text { production }\end{array}$} \\
\hline & $\begin{array}{l}\text { only } \\
\text { direct } \\
\text { content } \\
\text { (ICP) }\end{array}$ & $\begin{array}{l}\text { direct } \\
\text { and } \\
\text { indirect } \\
\text { content } \\
\text { (DIICP) }\end{array}$ & $\begin{array}{l}\text { only } \\
\text { direct } \\
\text { content } \\
\text { (ICE) }\end{array}$ & $\begin{array}{c}\text { direct } \\
\text { and } \\
\text { indirect } \\
\text { content } \\
\text { (DIICE) }\end{array}$ & & & \\
\hline & & & & 1995 & & & \\
\hline Total & 8.5 & 15.1 & 14.9 & 23.7 & 16.7 & 27.9 & 44.8 \\
\hline of which: Manufacturing & 16.9 & 26.0 & 17.6 & 27.1 & 25.6 & 37.8 & 30.1 \\
\hline Low-tech & 14.4 & 23.2 & 15.2 & 24.4 & 21.9 & 28.5 & 30.4 \\
\hline Medium-tech & 19.7 & 29.9 & 17.9 & 28.4 & 29.2 & 53.3 & 28.7 \\
\hline High-tech & 24.7 & 32.3 & 27.2 & 34.3 & 38.7 & 60.9 & 33.4 \\
\hline \multirow[t]{2}{*}{ of which: Market services } & 2.6 & 6.7 & 3.3 & 8.7 & 6.9 & 6.6 & 57.5 \\
\hline & & & & 2000 & & & \\
\hline Total & 8.9 & 15.6 & 16.8 & 25.4 & 16.9 & 29.7 & 42.9 \\
\hline of which: Manufacturing & 18.3 & 27.4 & 19.7 & 29.1 & 27.5 & 42.2 & 28.9 \\
\hline Low-tech & 15.1 & 24.0 & 16.6 & 26.0 & 22.8 & 30.7 & 29.2 \\
\hline Medium-tech & 21.5 & 31.4 & 20.2 & 30.3 & 31.4 & 57.1 & 27.3 \\
\hline High-tech & 27.8 & 34.5 & 30.1 & 36.1 & 43.2 & 72.0 & 32.4 \\
\hline \multirow[t]{2}{*}{ of which: Market services } & 2.9 & 7.6 & 3.6 & 9.2 & 6.9 & 6.9 & 53.7 \\
\hline & & & & 2007 & & & \\
\hline Total & 9.9 & 17.0 & 19.2 & 28.5 & 18.7 & 32.3 & 42.1 \\
\hline of which: Manufacturing & 21.3 & 31.1 & 22.8 & 33.0 & 31.4 & 47.6 & 27.1 \\
\hline Low-tech & 18.6 & 28.0 & 21.3 & 31.0 & 27.7 & 38.2 & 27.5 \\
\hline Medium-tech & 25.1 & 35.7 & 23.7 & 34.7 & 35.6 & 62.8 & 24.8 \\
\hline High-tech & 25.0 & 33.4 & 25.1 & 33.4 & 39.5 & 58.0 & 33.0 \\
\hline of which: Market services & 3.2 & 8.2 & 4.4 & 10.4 & 7.5 & 8.3 & 52.4 \\
\hline
\end{tabular}

Source: our calculations on Istat data.

Table 2. Measures of international outsourcing in Germany 


\begin{tabular}{|c|c|c|c|c|c|c|c|}
\hline \multirow[b]{2}{*}{ Sectors } & \multicolumn{2}{|c|}{$\begin{array}{l}\text { Import content of } \\
\text { production }\end{array}$} & \multicolumn{2}{|c|}{$\begin{array}{c}\text { Import content of } \\
\text { exports }\end{array}$} & \multirow[b]{2}{*}{$\begin{array}{c}\text { Imported } \\
\text { inputs on } \\
\text { Total } \\
\text { inputs } \\
\text { (IITI) }\end{array}$} & \multirow[b]{2}{*}{$\begin{array}{l}\text { Narrow } \\
\text { index }\end{array}$} & \multirow[b]{2}{*}{$\begin{array}{l}\text { Value } \\
\text { added on } \\
\text { production }\end{array}$} \\
\hline & $\begin{array}{c}\text { only } \\
\text { direct } \\
\text { content } \\
\text { (ICP) }\end{array}$ & $\begin{array}{l}\text { direct } \\
\text { and } \\
\text { indirect } \\
\text { content } \\
\text { (DIICP) }\end{array}$ & $\begin{array}{l}\text { only } \\
\text { direct } \\
\text { content } \\
\text { (ICE) }\end{array}$ & $\begin{array}{l}\text { direct } \\
\text { and } \\
\text { indirect } \\
\text { content } \\
\text { (DIICE) }\end{array}$ & & & \\
\hline & \multicolumn{7}{|c|}{1995} \\
\hline Total & 7.5 & 11.3 & 14.1 & 19.9 & 16.8 & 25.5 & 51.4 \\
\hline of which: Manufacturing & 14.1 & 20.4 & 15.6 & 22.1 & 23.6 & 33.6 & 36.2 \\
\hline Low-tech & 13.2 & 19.1 & 16.4 & 22.5 & 21.9 & 30.2 & 34.8 \\
\hline Medium-tech & 15.2 & 22.0 & 15.4 & 22.3 & 25.3 & 37.0 & 36.6 \\
\hline High-tech & 13.8 & 19.7 & 14.4 & 20.2 & 23.8 & 34.4 & 39.8 \\
\hline \multirow[t]{2}{*}{ of which: Market services } & 2.7 & 4.5 & 7.0 & 9.1 & 8.6 & 9.6 & 64.3 \\
\hline & \multicolumn{7}{|c|}{2000} \\
\hline Total & 9.8 & 14.8 & 17.2 & 24.2 & 20.2 & 31.3 & 47.1 \\
\hline of which: Manufacturing & 17.5 & 25.1 & 19.3 & 27.3 & 27.6 & 40.6 & 32.5 \\
\hline Low-tech & 15.3 & 21.7 & 19.2 & 25.7 & 25.2 & 37.8 & 34.1 \\
\hline Medium-tech & 19.1 & 28.0 & 19.4 & 28.2 & 28.7 & 41.1 & 29.5 \\
\hline High-tech & 18.6 & 25.6 & 19.5 & 26.3 & 30.6 & 44.8 & 37.3 \\
\hline \multirow[t]{2}{*}{ of which: Market services } & 4.2 & 7.0 & 7.6 & 10.6 & 11.4 & 15.3 & 59.1 \\
\hline & \multicolumn{7}{|c|}{2007} \\
\hline Total & 11.6 & 17.4 & 20.1 & 28.2 & 23.4 & 33.2 & 45.5 \\
\hline of which: Manufacturing & 20.4 & 29.5 & 22.4 & 31.4 & 31.3 & 41.2 & 30.0 \\
\hline Low-tech & 19.3 & 27.0 & 23.7 & 31.3 & 30.2 & 42.7 & 29.7 \\
\hline Medium-tech & 20.9 & 31.4 & 21.1 & 31.4 & 31.1 & 38.3 & 28.7 \\
\hline High-tech & 21.4 & 29.3 & 24.4 & 32.0 & 34.6 & 47.2 & 35.8 \\
\hline of which: Market services & 4.6 & 7.6 & 8.7 & 12.0 & 13.0 & 17.2 & 59.1 \\
\hline
\end{tabular}

Source: our calculations on Eurostat data.

Figure 1. International outsourcing

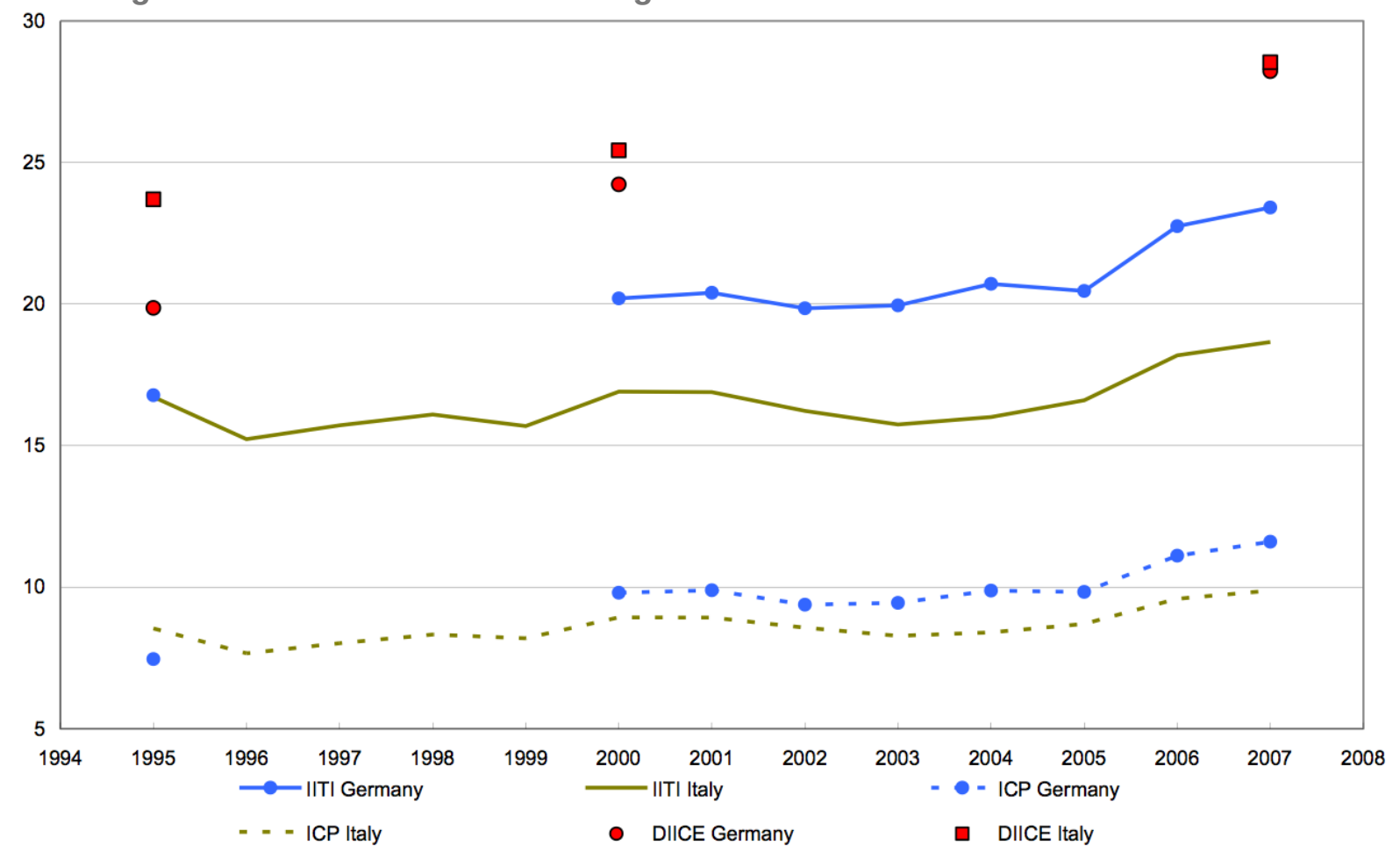


Source: our calculations on Eurostat and Istat data.

Figure 2. International outsourcing in manufacturing

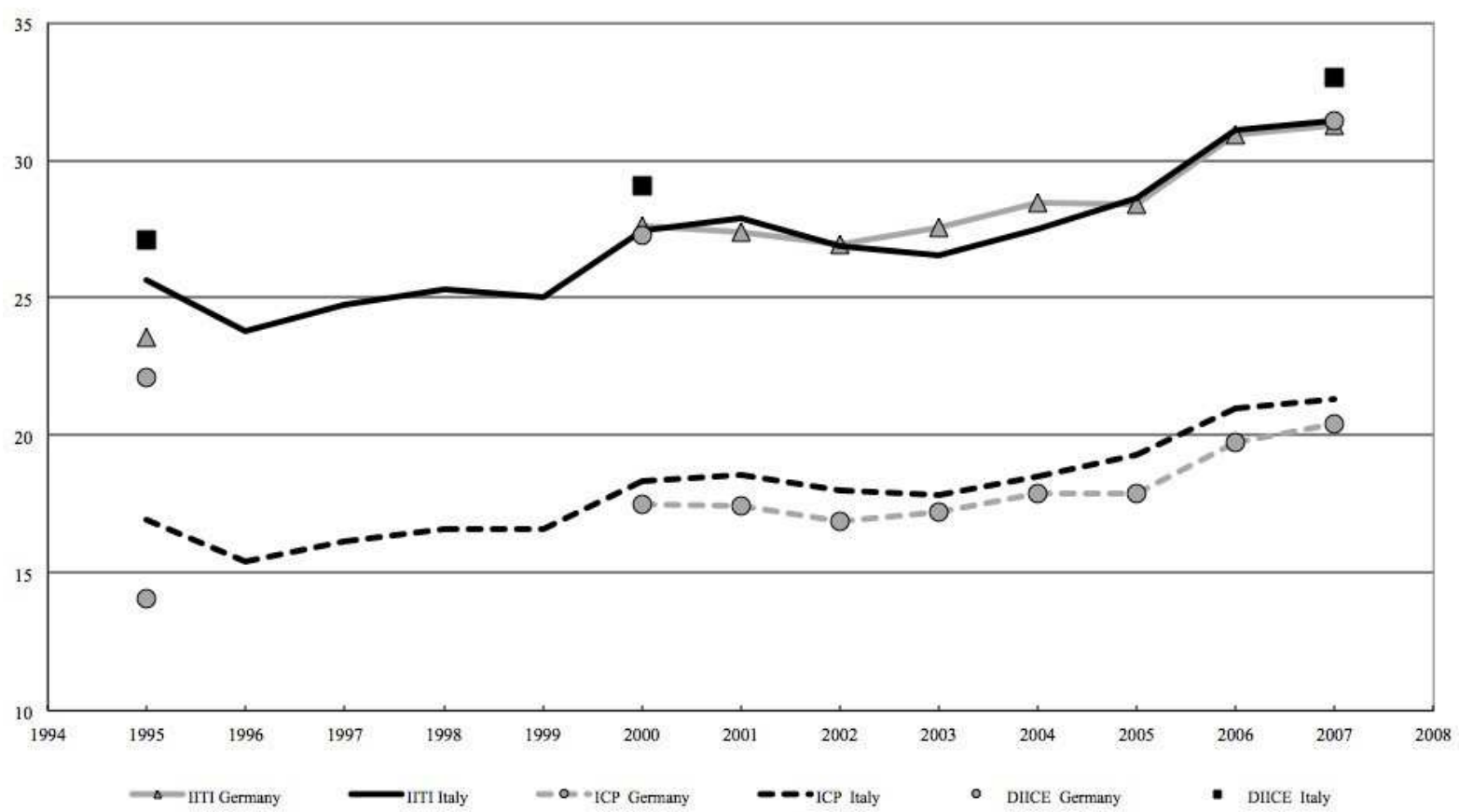

Source: our calculations on Eurostat and Istat data.

Figure 3. International outsourcing in services

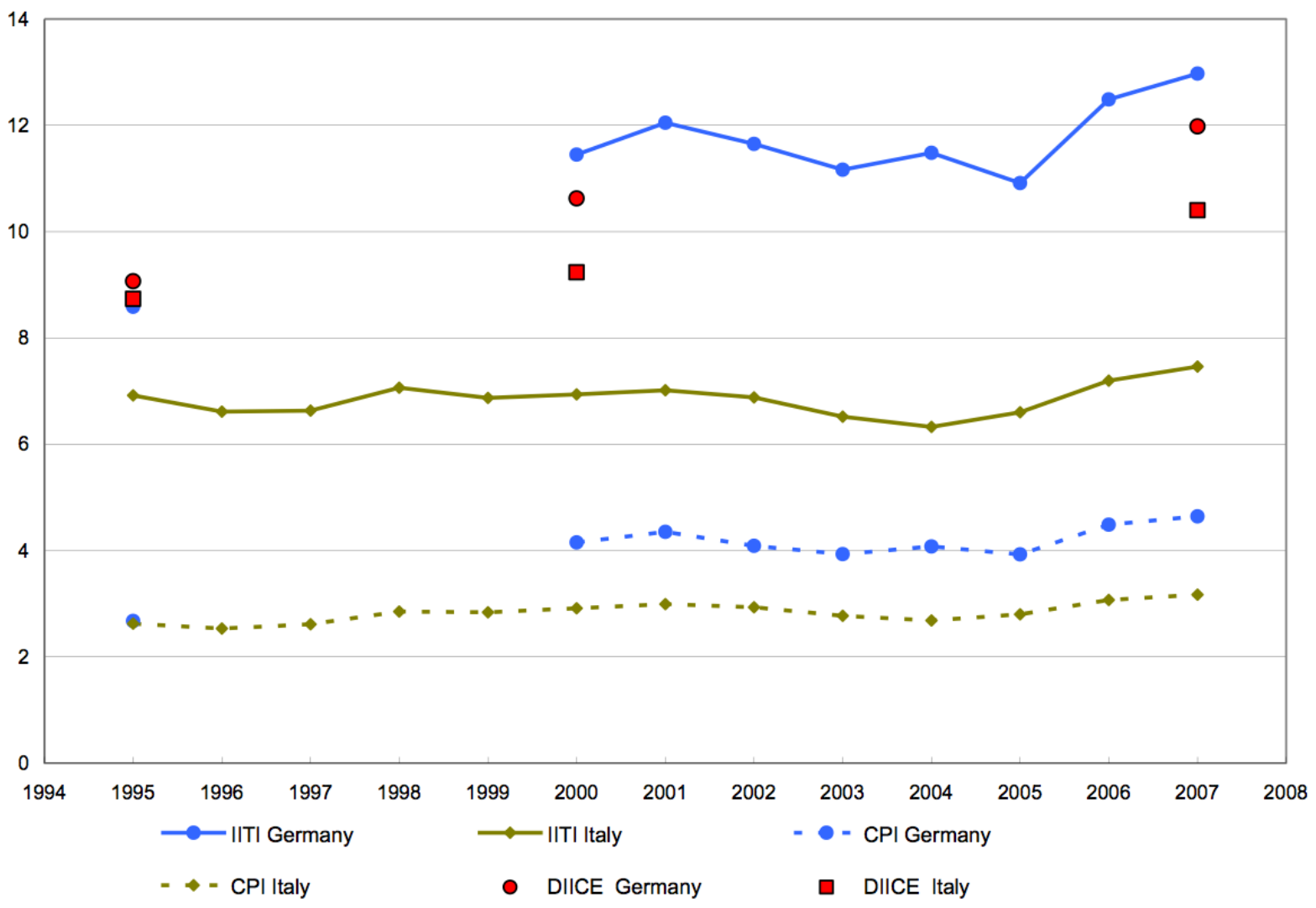

Source: our calculations on Eurostat and Istat data.

The level of international outsourcing in the two countries in 2007 appears to be comparable: as expected, international outsourcing is significantly less intense in the market services industry than in manufacturing sectors, mainly because of different production 
technologies (the service sector is usually more labour intensive than the manufacturing sector) and of weaker international competition. ${ }^{16}$

Overall, the international outsourcing indicators are higher for Germany than for Italy, but this is due entirely to the higher internationalisation of market services, which reflects a more intensive use of imported inputs in the German financial and banking sector.

On the other hand, almost all the indicators for Italy show a higher degree of international fragmentation in manufacturing, although the values for the two countries stand in a very narrow range. Therefore, at least from a static viewpoint, the "bazaar" label seems to be appropriate also for the Italian manufacturing sector. Indeed, an international comparison based on the ratio of imported intermediate inputs to total intermediate inputs in 2003, shows that Italy and Germany, along with the UK, are the most internationalised countries among the largest OECD economies. ${ }^{17}$

In the manufacturing sector, the highest international outsourcing values are found in hightech (notably office machinery) and medium-tech industries. In 2007, for every euro one hundred worth of goods produced in the high-technology sectors, the direct content of imported inputs in production (ICP) was around euro twenty-five in Italy and euro twenty-one in Germany, whereas the direct and indirect import content (DIICP) was euro thirty-three and euro twenty-nine, respectively.

Thus, the higher degree of international outsourcing in high and medium-tech industries largely compensates for Italy's more "traditional" specialisation, i.e., the higher relative weight of low-tech sectors -the least internationalised-compared to Germany.

To analyse the dynamics of these indices, tables 3 and 4 present the yearly average percentage changes of international outsourcing in Italy and Germany in the two periods.

Table 3. Development of international outsourcing in Italy

\footnotetext{
${ }^{16}$ Feenstra (1998) provides an interesting complementary explanation of the lower level of international fragmentation in the services industry with respect to manufacturing, which is based on the different ways in which goods trade and services trade are statistically measured. Every time an intermediate good crosses the border, the entire value of this good is counted in import or export statistics, whereas in intermediate services only the value-added is registered. The indicators of international fragmentation for manufacturing (and other merchandise) are therefore upward-biased because of the double-counting of value-added at numerators, and are magnified by the number of cross-border transactions. Chen et al. (2005) try to assess the quantitative importance of such double-counting in manufacturing data by estimating homogenous indicators for vertical specialisation in manufacturing and services.

${ }^{17}$ See OECD (2007, p. 36, figure 2.12).
} 


\begin{tabular}{|c|c|c|c|c|c|c|c|}
\hline \multirow[b]{2}{*}{ Sectors } & \multicolumn{2}{|c|}{$\begin{array}{l}\text { Import content of } \\
\text { production }\end{array}$} & \multicolumn{2}{|c|}{$\begin{array}{l}\text { Import content of } \\
\text { exports }\end{array}$} & \multirow{2}{*}{$\begin{array}{l}\text { Imported } \\
\text { inputs on } \\
\text { Total } \\
\text { inputs } \\
\text { (IITI) }\end{array}$} & \multirow[b]{2}{*}{$\begin{array}{l}\text { Narrow } \\
\text { index }\end{array}$} & \multirow[b]{2}{*}{$\begin{array}{l}\text { Value added } \\
\text { on } \\
\text { production }\end{array}$} \\
\hline & $\begin{array}{l}\text { only } \\
\text { direct } \\
\text { content } \\
\text { (ICP) }\end{array}$ & $\begin{array}{l}\text { direct and } \\
\text { indirect } \\
\text { content } \\
\text { (DIICP) }\end{array}$ & $\begin{array}{l}\text { only } \\
\text { direct } \\
\text { content } \\
\text { (ICE) }\end{array}$ & $\begin{array}{l}\text { direct and } \\
\text { indirect } \\
\text { content } \\
\text { (DIICE) }\end{array}$ & & & \\
\hline & \multicolumn{7}{|c|}{ Yearly average percentage variation $1995-2000$} \\
\hline Total & 0.9 & 0.7 & 2.4 & 1.4 & 0.2 & 1.2 & -0.8 \\
\hline of which: Manufacturing & 1.6 & 1.0 & 2.3 & 1.4 & 1.4 & 2.2 & -0.9 \\
\hline Low-tech & 1.0 & 0.7 & 1.8 & 1.3 & 0.8 & 1.5 & -0.8 \\
\hline Medium-tech & 1.7 & 1.0 & 2.5 & 1.4 & 1.4 & 1.4 & -1.0 \\
\hline High-tech & 2.4 & 1.3 & 2.1 & 1.0 & 2.2 & 3.4 & -0.6 \\
\hline \multirow[t]{2}{*}{ of which: Market services } & 2.1 & 2.4 & 1.7 & 1.1 & 0.1 & 1.1 & -1.4 \\
\hline & \multicolumn{7}{|c|}{ Yearly average percentage variation $2000-2007$} \\
\hline Total & 1.5 & 1.2 & 2.0 & 1.7 & 1.4 & 1.2 & -0.3 \\
\hline of which: Manufacturing & 2.2 & 1.8 & 2.1 & 1.8 & 2.0 & 1.7 & -0.9 \\
\hline Low-tech & 3.0 & 2.2 & 3.6 & 2.5 & 2.8 & 3.1 & -0.9 \\
\hline Medium-tech & 2.2 & 1.8 & 2.3 & 1.9 & 1.8 & 1.4 & -1.3 \\
\hline High-tech & -1.5 & -0.4 & -2.6 & -1.1 & -1.3 & -3.0 & 0.3 \\
\hline \multirow[t]{2}{*}{ of which: Market services } & 1.2 & 1.1 & 3.1 & 1.7 & 1.0 & 2.6 & -0.4 \\
\hline & \multicolumn{7}{|c|}{ Yearly average percentage variation $1995-2007$} \\
\hline Total & 1.2 & 1.0 & 2.1 & 1.6 & 0.9 & 1.2 & -0.5 \\
\hline of which: Manufacturing & 2.0 & 1.5 & 2.2 & 1.7 & 1.7 & 1.9 & -0.9 \\
\hline Low-tech & 2.2 & 1.6 & 2.9 & 2.0 & 2.0 & 2.5 & -0.9 \\
\hline Medium-tech & 2.0 & 1.5 & 2.4 & 1.7 & 1.7 & 1.4 & -1.2 \\
\hline High-tech & 0.1 & 0.3 & -0.7 & -0.2 & 0.2 & -0.4 & -0.1 \\
\hline of which: Market services & 1.6 & 1.6 & 2.5 & 1.5 & 0.6 & 2.0 & -0.8 \\
\hline
\end{tabular}

Source: our calculations on Istat data.

Table 4. Development of international outsourcing in Germany 


\begin{tabular}{|c|c|c|c|c|c|c|c|}
\hline \multirow[b]{2}{*}{ Sectors } & \multicolumn{2}{|c|}{$\begin{array}{l}\text { Import content of } \\
\text { production }\end{array}$} & \multicolumn{2}{|c|}{$\begin{array}{l}\text { Import content of } \\
\text { exports }\end{array}$} & \multirow[b]{2}{*}{$\begin{array}{l}\text { Imported } \\
\text { inputs on } \\
\text { Total } \\
\text { inputs } \\
\text { (IITI) }\end{array}$} & \multirow[b]{2}{*}{$\begin{array}{l}\text { Narrow } \\
\text { index }\end{array}$} & \multirow[b]{2}{*}{$\begin{array}{c}\text { Value } \\
\text { added on } \\
\text { production }\end{array}$} \\
\hline & $\begin{array}{l}\text { only } \\
\text { direct } \\
\text { content } \\
\text { (ICP) }\end{array}$ & $\begin{array}{l}\text { direct } \\
\text { and } \\
\text { indirect } \\
\text { content } \\
\text { (DIICP) }\end{array}$ & $\begin{array}{l}\text { only } \\
\text { direct } \\
\text { content } \\
\text { (ICE) }\end{array}$ & $\begin{array}{l}\text { direct } \\
\text { and } \\
\text { indirect } \\
\text { content } \\
\text { (DIICE) }\end{array}$ & & & \\
\hline & \multicolumn{7}{|c|}{ Yearly average percentage variation $1995-2000$} \\
\hline Total & 5.6 & 5.5 & 4.0 & 4.1 & 3.8 & 4.2 & -1.7 \\
\hline of which: Manufacturing & 4.4 & 4.3 & 4.4 & 4.3 & 3.2 & 3.8 & -2.1 \\
\hline Low-tech & 3.0 & 2.6 & 3.1 & 2.6 & 2.8 & 4.6 & -0.4 \\
\hline Medium-tech & 4.7 & 5.0 & 4.6 & 4.9 & 2.5 & 2.2 & -4.2 \\
\hline High-tech & 6.1 & 5.4 & 6.3 & 5.4 & 5.1 & 5.5 & -1.3 \\
\hline \multirow[t]{2}{*}{ of which: Market services } & 9.2 & 9.2 & 1.7 & 3.2 & 5.9 & 9.8 & -1.7 \\
\hline & \multicolumn{7}{|c|}{ Yearly average percentage variation $2000-2007$} \\
\hline Total & 2.4 & 2.3 & 2.3 & 2.2 & 2.1 & 0.8 & -0.5 \\
\hline of which: Manufacturing & 2.2 & 2.3 & 2.1 & 2.0 & 1.8 & 0.2 & -1.1 \\
\hline Low-tech & 3.4 & 3.2 & 3.1 & 2.8 & 2.6 & 1.8 & -2.0 \\
\hline Medium-tech & 1.3 & 1.6 & 1.3 & 1.5 & 1.1 & -1.0 & -0.4 \\
\hline High-tech & 2.0 & 2.0 & 3.3 & 2.8 & 1.7 & 0.7 & -0.6 \\
\hline \multirow[t]{2}{*}{ of which: Market services } & 1.6 & 1.1 & 2.0 & 1.7 & 1.8 & 1.7 & 0.0 \\
\hline & \multicolumn{7}{|c|}{ Yearly average percentage variation $1995-2007$} \\
\hline Total & 3.8 & 3.7 & 3.0 & 3.0 & 2.8 & 2.2 & -1.0 \\
\hline of which: Manufacturing & 3.1 & 3.1 & 3.1 & 3.0 & 2.4 & 1.7 & -1.6 \\
\hline Low-tech & 3.2 & 2.9 & 3.1 & 2.8 & 2.7 & 2.9 & -1.3 \\
\hline Medium-tech & 2.7 & 3.0 & 2.7 & 2.9 & 1.7 & 0.3 & -2.0 \\
\hline High-tech & 3.7 & 3.4 & 4.5 & 3.9 & 3.1 & 2.7 & -0.9 \\
\hline of which: Market services & 4.7 & 4.4 & 1.9 & 2.4 & 3.5 & 5.0 & -0.7 \\
\hline
\end{tabular}

Source: our calculations on Eurostat data.

The results clearly show a significant increase in international fragmentation from 1995 to 2007 for all levels of industry aggregation in Germany according to almost all the indices. The increase in international outsourcing activities was slightly stronger in high-tech than in low-tech industries.

Also in the case of Italy, all the indicators for the whole economy show an increase in the level of outsourcing between 1995 and 2007 (table 3, third part). However, the growth in Italy's indicators is slower than Germany's, reflecting both a slower growth of internationalisation in Italian manufacturing firms, characterised by a higher level of outsourcing than their German counterparts in 1995, and the increasing relative importance of market services industries, which are structurally characterised by a lower intensity of imported inputs.

Moreover, looking at total export market shares shows a different pattern emerging in the two countries: while Italian exports lost market share during the entire period (1995-2007) and in both sub-periods (1995-2000 and 2000-2007), German exports were more resilient, especially in terms of the share at constant prices (figure 4). ${ }^{18}$

Figure 4. Export market shares of Germany and Italy*

\footnotetext{
${ }^{18}$ The evolution of the market shares at constant prices and exchange rates can be partly biased by statistical problems in the measurement of export unit values, which are used as deflators. In particular, Italian export unit values systematically overestimate the dynamics of the corresponding export prices, while the opposite seems to be true for German export unit values. However, considering the exports' market shares at current prices and exchange rates (that do not suffer from the above-mentioned measurement problems and seem more appropriate for analysing medium-long periods of time), we see that between 1995 and 2006 Italy lost almost one quarter of its market share, Germany only less than one tenth.
} 


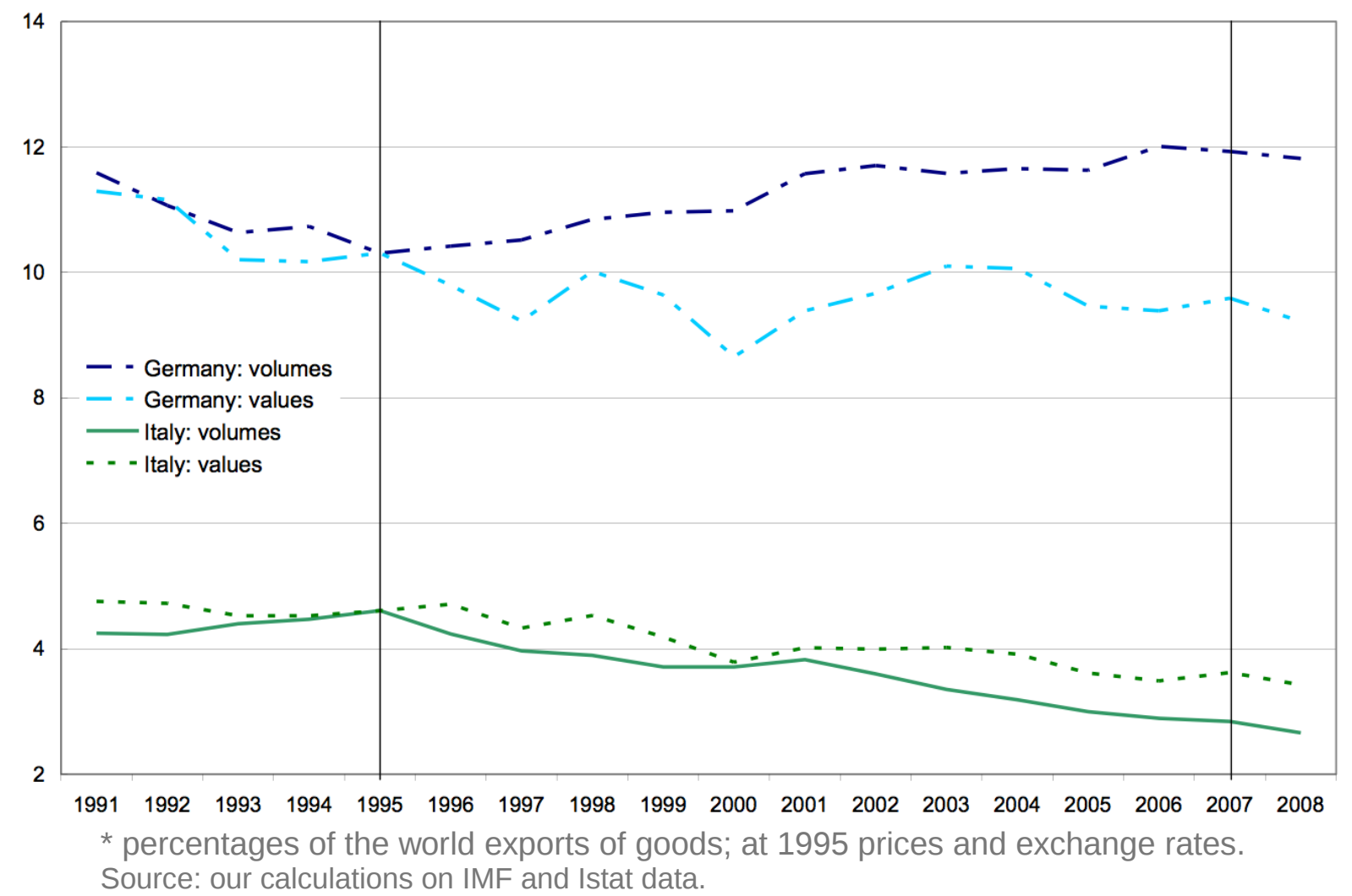

In a period that saw the major developing countries enter the world trade market (China and India being the most relevant examples), developed countries naturally lost export market shares. Italy was no exception, although Germany actually increased its share especially in 2000-2007, the second sub-period. The faster growth of internationalisation in German manufacturing has had, at the least, a simple impact on this development as it has inflated German trade exchanges, which include both the exports of final goods and the intermediate goods sent abroad for processing. On the other hand, further analysis is needed to test the extent of the growing internationalisation of production (especially by means of a reduction in labour costs) on the competitiveness of German manufactured goods.

\subsection{A look at manufacturing industries}

To obtain a more detailed picture, we shifted the analysis to outsourcing at the disaggregated industry level. Figures 5 and 6 show the development of some of the indices proposed for international outsourcing in manufacturing in 1995-2007 for Italy and Germany, respectively.

Figure 5. Sectoral development of IITI_broad (a), IITI_narrow (b), ICP (c) and DIICP (d) in Italy

a. 


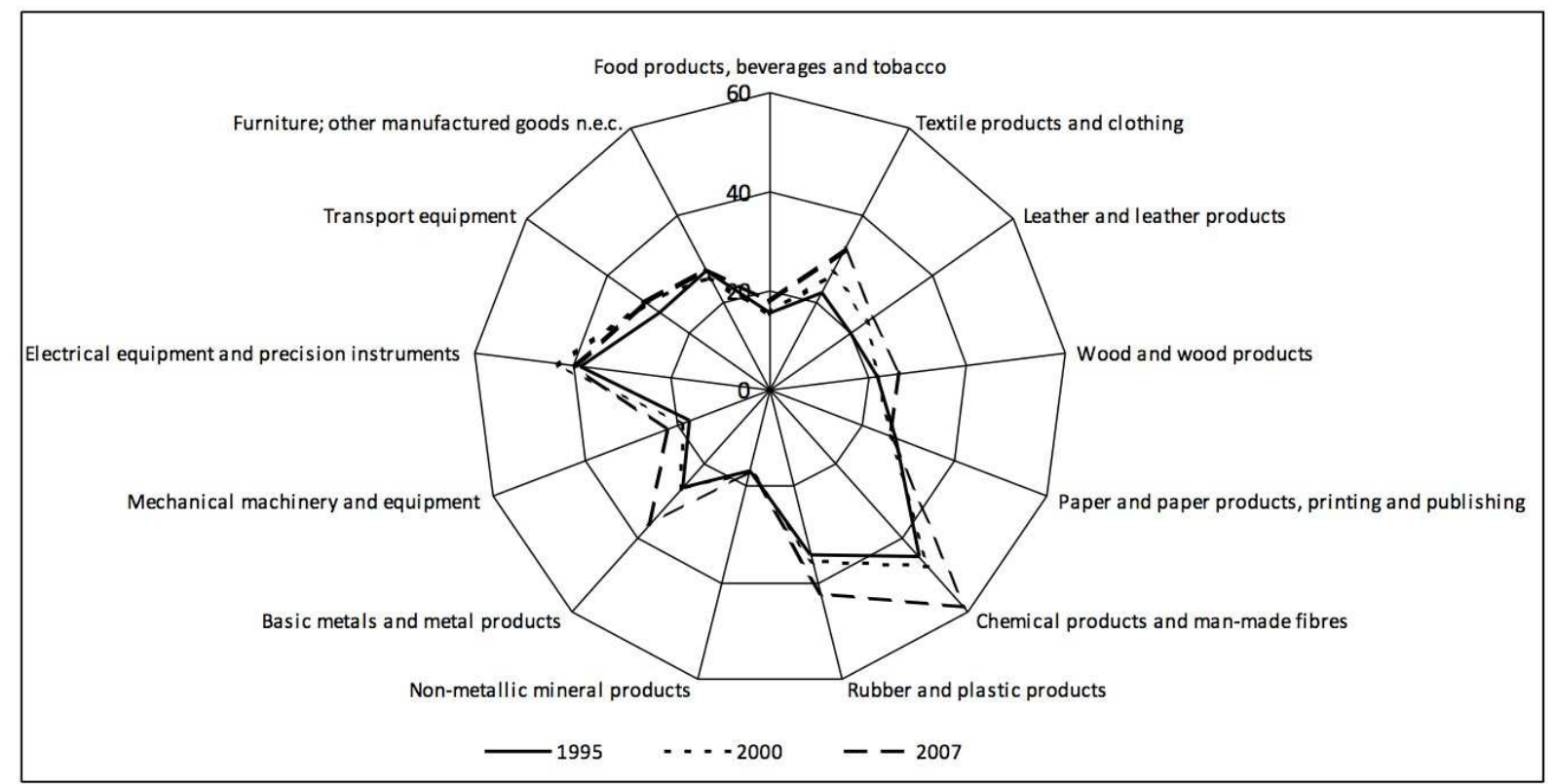

b.

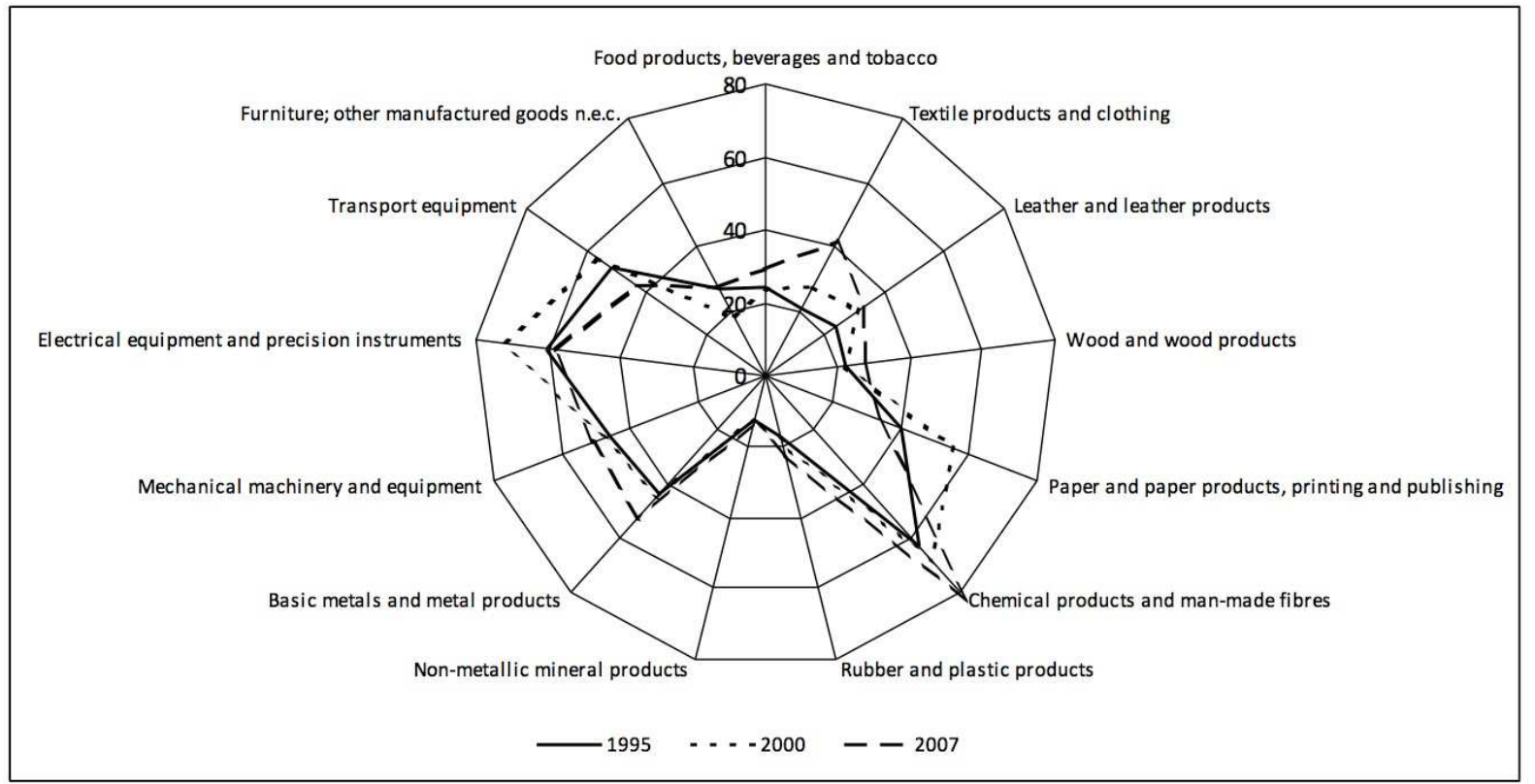

c. 


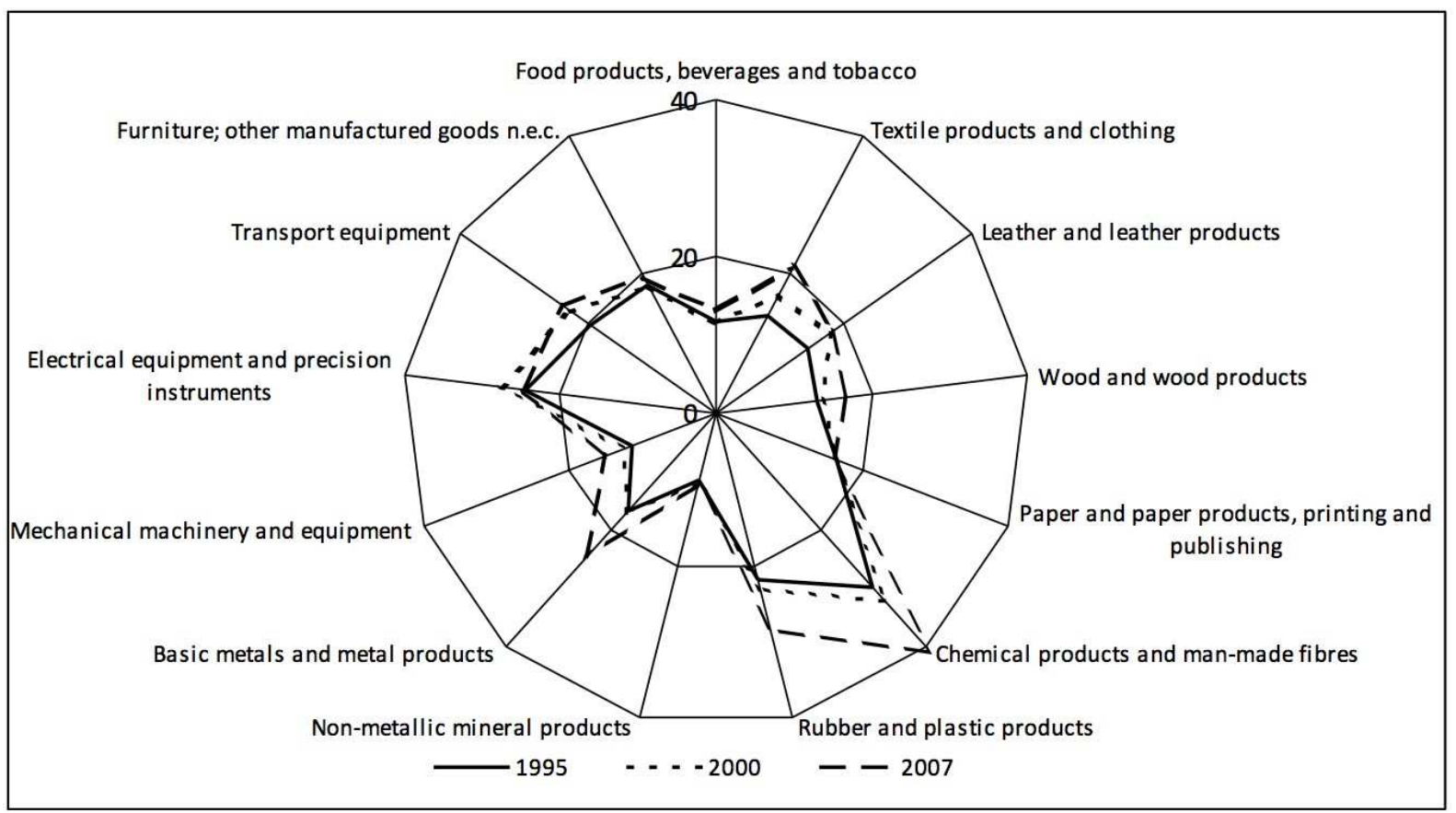

d.

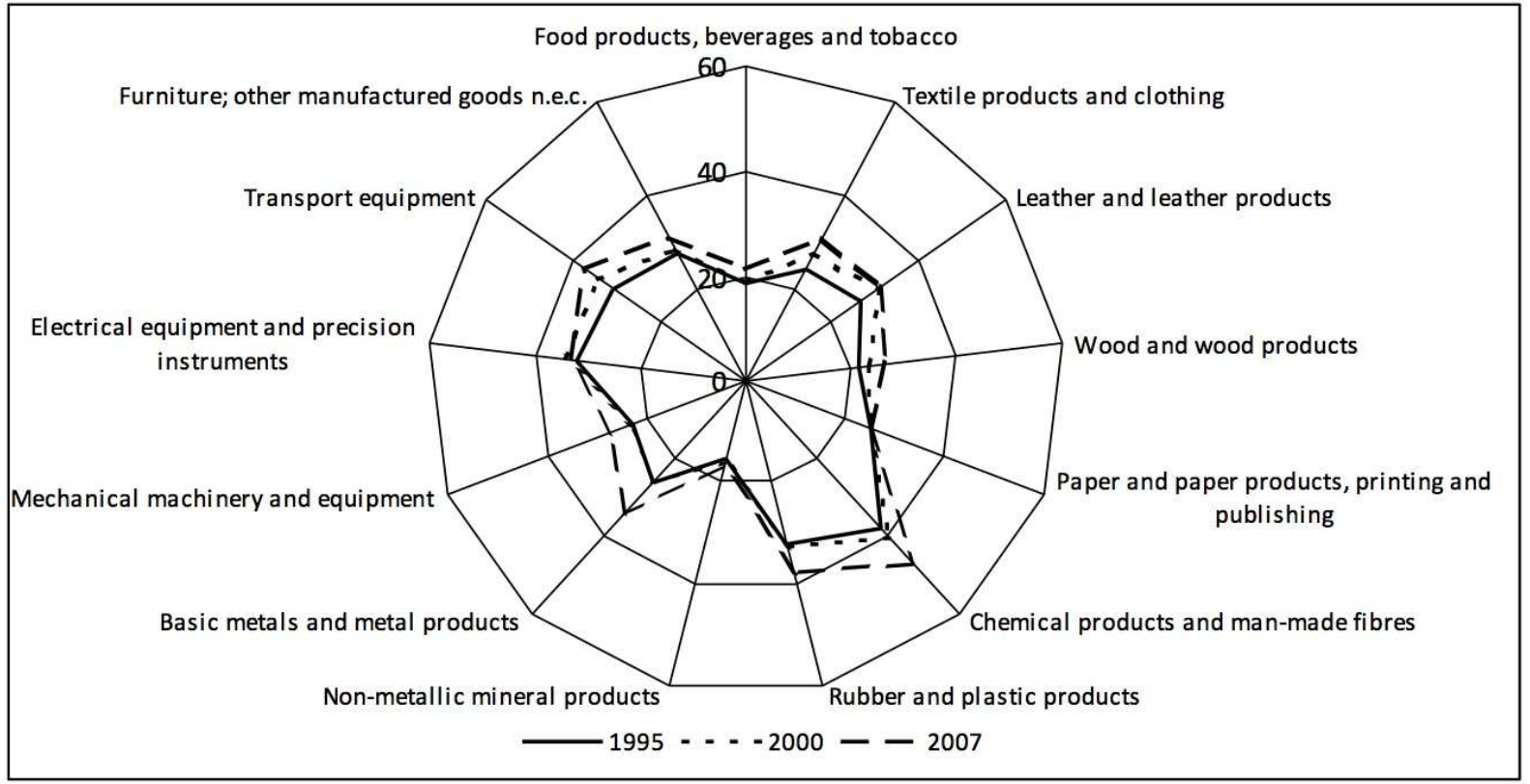

Source: our calculations on Istat data.

Figure 6. Sectoral development of IITI_broad (a), IITI_narrow (b), ICP (c) and DIICP (d) in Germany

a. 


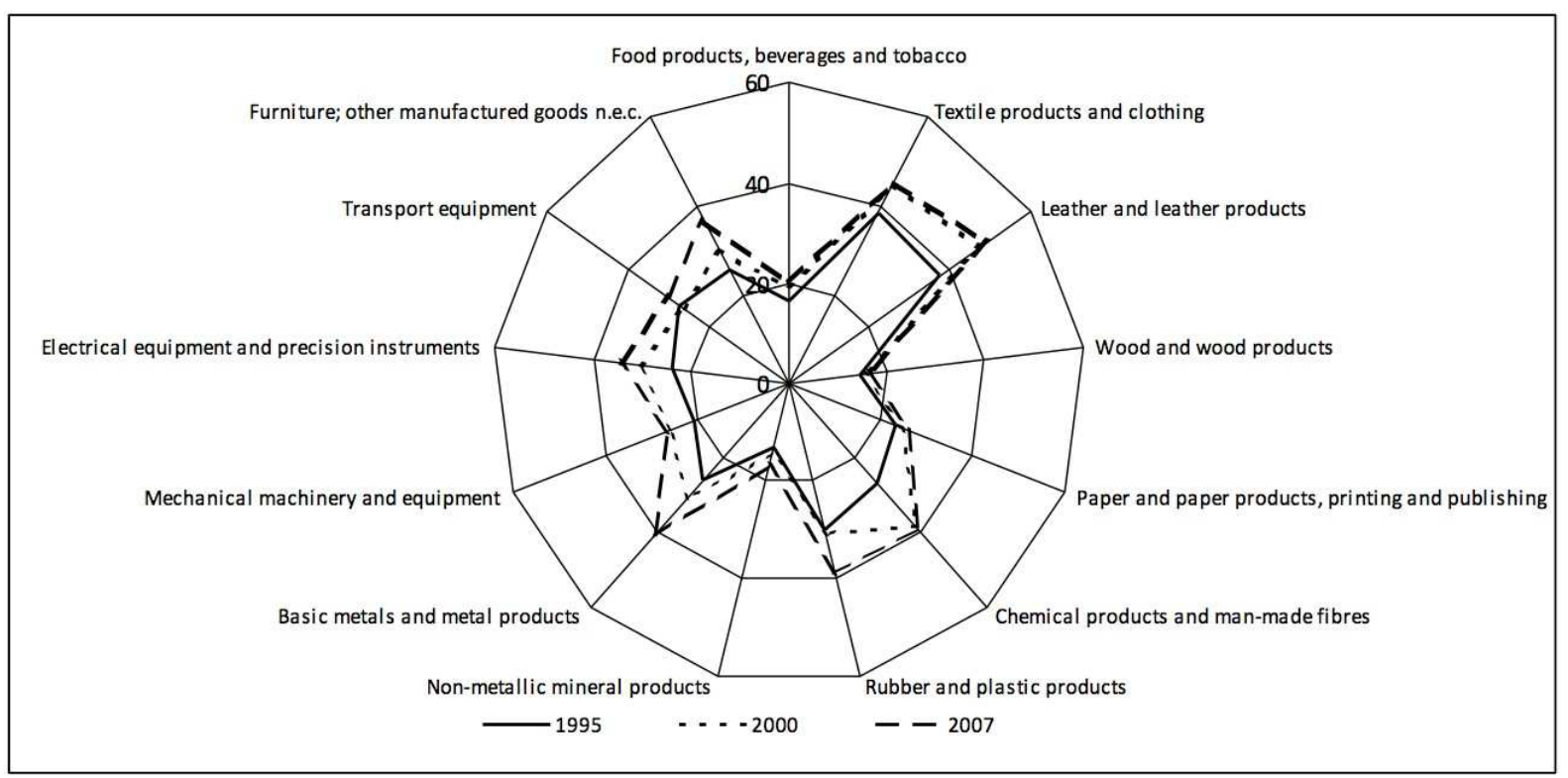

b.

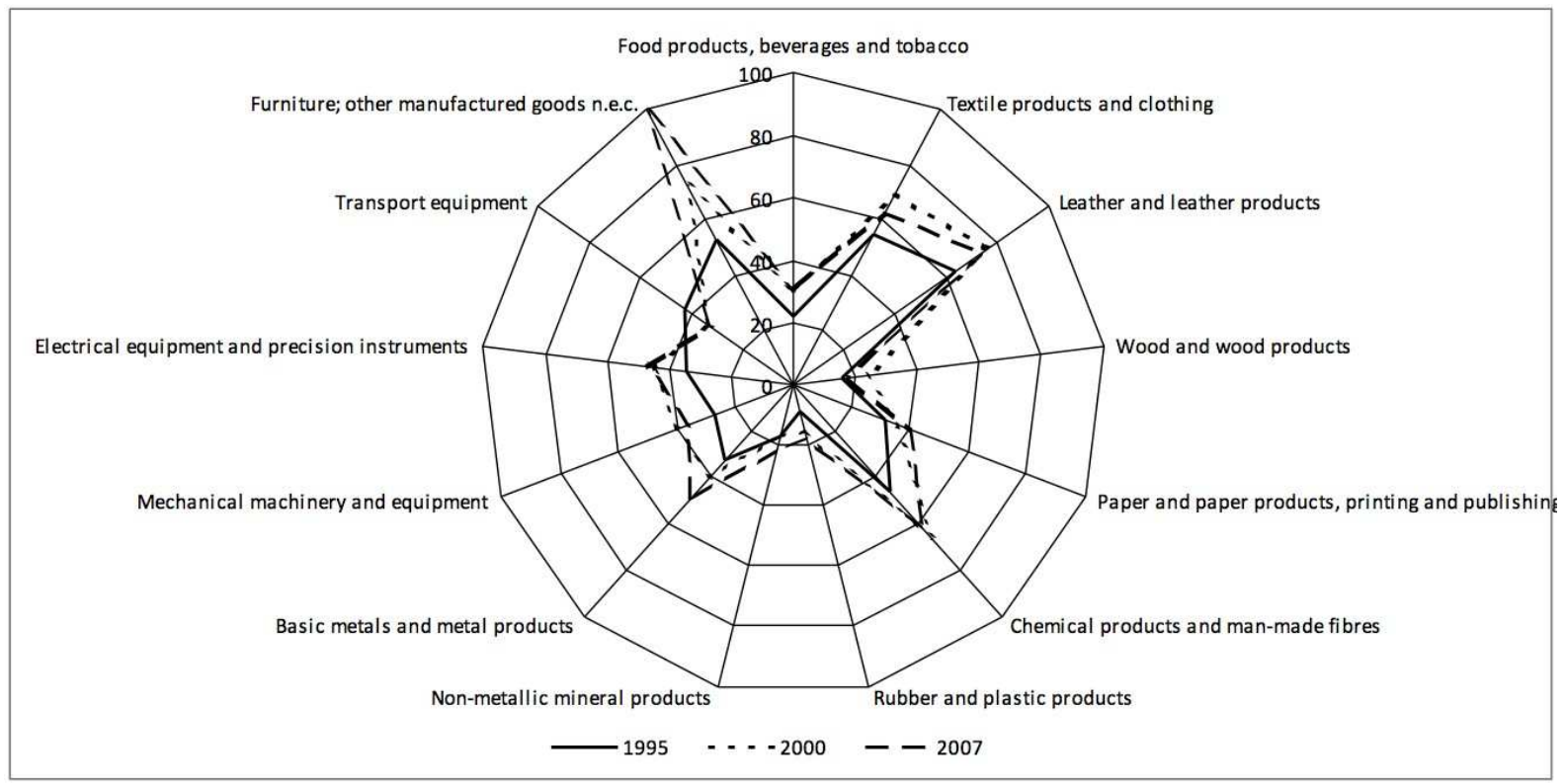

c. 


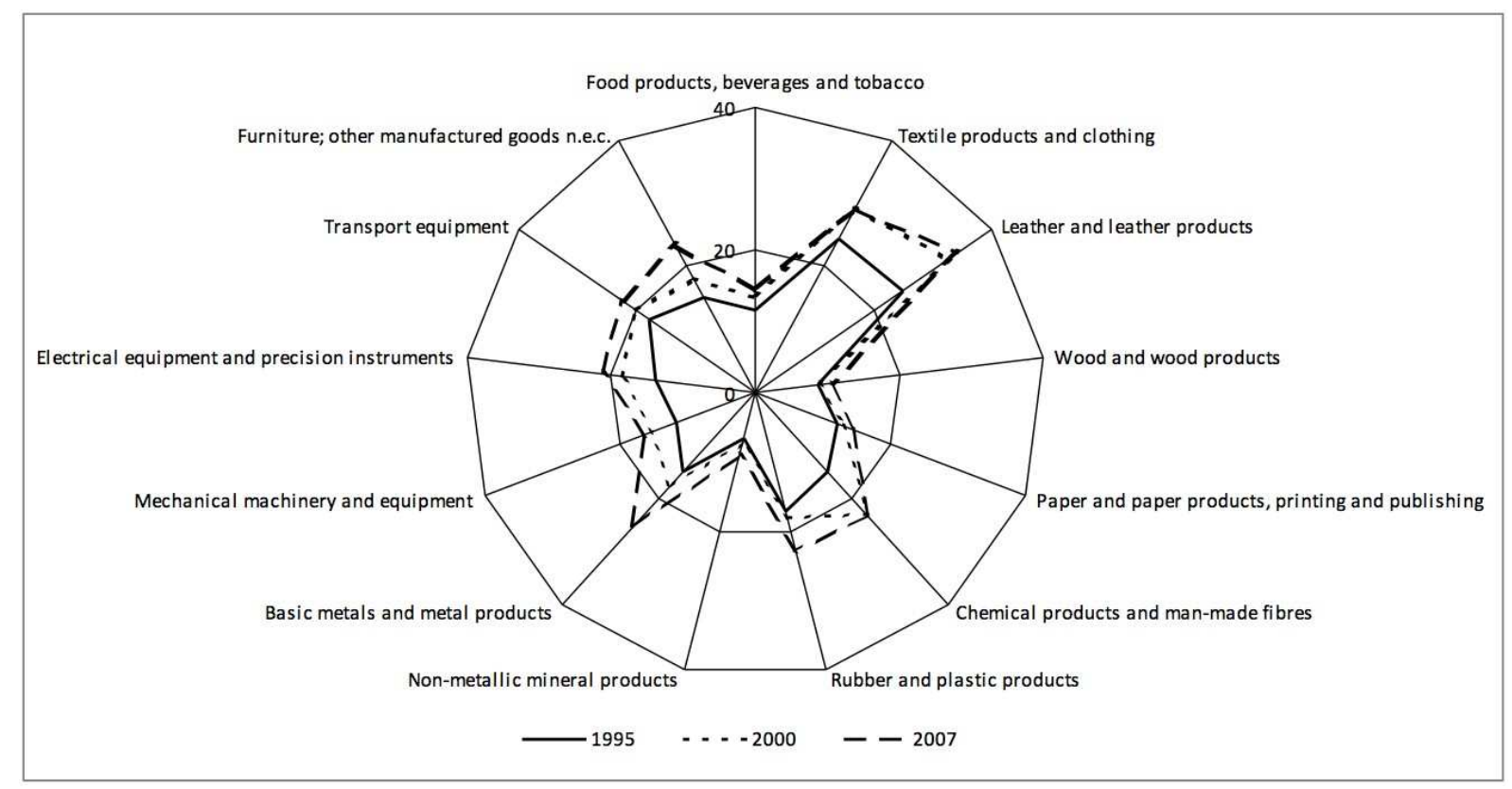

d.

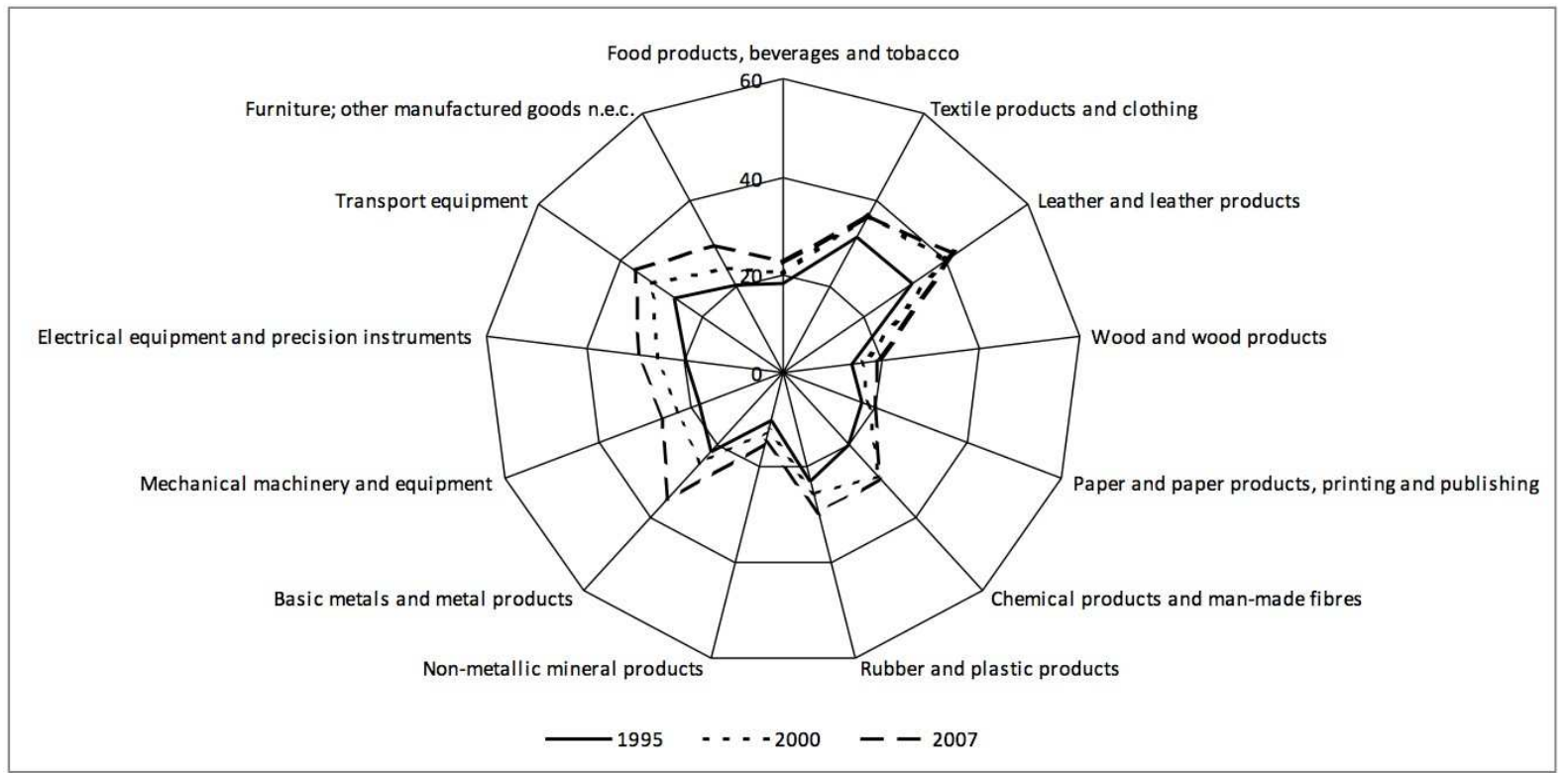

Source: our calculations on Eurostat data.

The intensity of off-shoring is fairly different across industries. In 2007, the outsourcing intensity of in Italy's chemicals and electrical equipment industries was equal to $60 \%$ and $40 \%$, respectively, as measured by the IITI_broad index (figure 5a), while the outsourcing intensity of the machinery industry, the most significant Italian manufacturing segment, amounted to as much as half (about 20\%). The ICP indicator confirms both the ranking among industries and their development in the 12-year period (figure 5c). On the other hand, looking at the narrow outsourcing indicator (figure 5b), which takes account of solely intraindustry trade, a quite different picture emerges: chemical and electrical equipment industries remain the most internationally integrated, although the mechanical industry appears to be fairly internationally integrated too, given that about $50 \%$ of all its intra-industry inputs are imported from abroad: this fact implies that the extra-industry inputs of mechanical products are almost completely domestic, thus suggesting a possible specialisation of the sector in high-quality products.

In Germany, the ranking of industries by intensity of international outsourcing seems to be even more dependent on the indicator used. When the IITI_broad and the IITI_narrow indices 
are used (figures 6a and 6b), chemicals, as well as the metal and electrical equipment industries, show the highest levels of outsourcing intensity, while transport equipment appears more internationalised when analysing the imported inputs on production (ICP index); this is true particularly when both direct and indirect import contents are considered, suggesting that German transport equipment firms outsource the production of lower-quality parts and/or final products abroad, keeping only the higher-quality production phases in Germany. Also "textile products and clothing" and "leather and leather products" show a very high level of international outsourcing, but their relative weight on Germany's total manufacturing production is almost nil.

The contribution to the overall increase of outsourcing in manufacturing in the 12-year period can be explained in the case of Germany by metals, electrical equipment and chemical products, while in Italy the growth of international outsourcing has been driven by metals, chemicals and some traditional industries, in particular "textile products and clothing".

Despite the differing levels of international outsourcing in both countries, the outsourcing intensity in almost all industries was higher in 2007 than in 1995. A notable exception being the electrical equipment industry in Italy, among the relatively more important industries for its economy, where outsourcing decreased slightly from its 1995 level. As the size of this sector has contracted in Italy, this decrease could indicate an increasing specialisation in niche products, which would enable Italian firms to exert some monopolistic pressure and use a larger share of high-quality domestic inputs. ${ }^{19}$ Finally, all indicators except narrow outsourcing for transport equipment show an increase in the internationalisation of both countries. ${ }^{20}$

\section{A shift and share analysis}

Although all these indices are mainly focused on international outsourcing, there are also other forces driving their evolution. For example, an index can rise if a highly vertically specialised sector increases its share of the production of the whole economy, even when the outsourcing activity of the sector did not change at all or even declined. Using a shift and share approach enables us to divide the variance of the indices into two parts across sectors: the change of intensity in industries' international outsourcing (the within component $I O_{i}$ ) and the relative change of the economy's structure (the between component $\left.\theta_{i}\right)^{21}$, according to the following formula:

$$
\Delta I N D E X_{z}=\sum_{i=1}^{n} \bar{\theta}_{i} \Delta I O_{i}+\sum_{i=1}^{n} \Delta \theta_{i} \overline{I O}_{i}
$$

with $I N D E X_{z}$ as the value of the index $z$ ( $z=I I T I \_b r o a d, I I T I \_n a r r o w, I C P, D I I C P, I C E$, $D I I C E$ and $V A P$ ) and $\triangle$ indicating absolute changes. By using a bar for the statistical mean of the value in the 1995-2007 period, one component is kept constant in order to isolate the

\footnotetext{
${ }^{19}$ For example, the electrical equipment sector includes lighting equipment, a market segment in which Italian firms are firmly established, above all thanks to their high-quality design.

${ }^{20}$ This phenomenon could be explained, at least partly, by a sizeable reduction of the relative price of imported parts and components produced in the same sector (i.e. transport equipment) with respect to the other inputs used; this reduction, obtained by outsourcing to lower-cost countries, could (more than) offset the effect of the rising share in volume terms of parts and components on total inputs.

${ }^{21}$ The structural component differs with respect to the various indices. For example, in the case of the ICP index, the structural component is the share of the output of industry $i$ to the economy wide output, whereas for the IITI index it is the share of the total inputs of sector $i$ to economy wide total inputs. The within component, instead, captures the variation of the sector's international outsourcing activity focusing on the imported inputs.
} 
variation of the other component, which is allowed to adjust. Therefore,

the change in international outsourcing only, while

$$
\sum_{i=1}^{n} \Delta \theta_{i} \overline{I O}_{i}
$$
changes.

captures only structural

Tables 5 and 6 present the results. The total rows depict the overall change in the index, i.e. the sum of the within and the between components. The within rows show the actual variation of outsourcing intensity in each sector.

Table 5. Outsourcing and sectoral changes in Italy (1995-2007)

\begin{tabular}{|c|c|c|c|c|c|c|c|}
\hline \multirow[b]{2}{*}{ Sectors } & \multicolumn{2}{|c|}{$\begin{array}{l}\text { Import content of } \\
\text { production }\end{array}$} & \multicolumn{2}{|c|}{$\begin{array}{l}\text { Import content of } \\
\text { exports }\end{array}$} & \multirow{2}{*}{$\begin{array}{l}\text { Imported } \\
\text { inputs on } \\
\text { Total } \\
\text { inputs } \\
\text { (IITI) }\end{array}$} & \multirow[b]{2}{*}{$\begin{array}{l}\text { Narrow } \\
\text { index }\end{array}$} & \multirow[b]{2}{*}{$\begin{array}{l}\text { Value } \\
\text { added on } \\
\text { production }\end{array}$} \\
\hline & $\begin{array}{l}\text { only direct } \\
\text { content } \\
\text { (ICP) }\end{array}$ & $\begin{array}{l}\text { direct and } \\
\text { indirect } \\
\text { content } \\
\text { (DIICP) }\end{array}$ & $\begin{array}{l}\text { only direct } \\
\text { content } \\
\text { (ICE) }\end{array}$ & $\begin{array}{l}\text { direct and } \\
\text { indirect } \\
\text { content } \\
\text { (DIICE) }\end{array}$ & & & \\
\hline & \multicolumn{7}{|c|}{ Total } \\
\hline Within & 2.09 & 2.88 & 4.32 & 4.96 & 3.20 & 5.43 & -4.19 \\
\hline Between & -0.74 & -0.96 & -0.05 & -0.12 & -1.24 & -1.04 & 1.47 \\
\hline \multirow[t]{2}{*}{ Total } & 1.35 & 1.92 & 4.27 & 4.84 & 1.96 & 4.39 & -2.72 \\
\hline & \multicolumn{7}{|c|}{ Manufacturing } \\
\hline Within & 4.66 & 5.18 & 5.08 & 5.64 & 5.94 & 7.93 & -3.30 \\
\hline Between & -0.25 & -0.12 & 0.20 & 0.28 & -0.18 & 1.87 & 0.13 \\
\hline \multirow[t]{2}{*}{ Total } & 4.41 & 5.06 & 5.28 & 5.92 & 5.75 & 9.80 & -3.16 \\
\hline & \multicolumn{7}{|c|}{ Market services } \\
\hline Within & 0.49 & 1.54 & 1.15 & 2.08 & 0.38 & 1.20 & -5.97 \\
\hline Between & 0.06 & -0.10 & -0.01 & -0.41 & 0.16 & 0.54 & 0.85 \\
\hline Total & 0.54 & 1.44 & 1.14 & 1.67 & 0.54 & 1.75 & -5.12 \\
\hline
\end{tabular}

Source: our calculations on Istat data.

Table 6. Outsourcing and sectoral changes in Germany (1995-2007)

\begin{tabular}{|c|c|c|c|c|c|c|c|}
\hline \multirow[b]{2}{*}{ Sectors } & \multicolumn{2}{|c|}{$\begin{array}{l}\text { Import content of } \\
\text { production }\end{array}$} & \multicolumn{2}{|c|}{$\begin{array}{c}\text { Import content of } \\
\text { exports }\end{array}$} & \multirow{2}{*}{$\begin{array}{c}\text { Imported } \\
\text { inputs on } \\
\text { Total } \\
\text { inputs } \\
\text { (IITI) }\end{array}$} & \multirow[b]{2}{*}{$\begin{array}{l}\text { Narrow } \\
\text { index }\end{array}$} & \multirow[b]{2}{*}{$\begin{array}{l}\text { Value } \\
\text { added on } \\
\text { production }\end{array}$} \\
\hline & $\begin{array}{l}\text { only direct } \\
\text { content } \\
\text { (ICP) }\end{array}$ & $\begin{array}{l}\text { direct and } \\
\text { indirect } \\
\text { content } \\
\text { (DIICP) }\end{array}$ & $\begin{array}{l}\text { only direct } \\
\text { content } \\
\text { (ICE) }\end{array}$ & $\begin{array}{l}\text { direct and } \\
\text { indirect } \\
\text { content } \\
\text { (DIICE) }\end{array}$ & & & \\
\hline & \multicolumn{7}{|c|}{ Total } \\
\hline Within & 3.31 & 5.03 & 5.19 & 7.53 & 5.10 & 5.66 & -5.06 \\
\hline Between & 0.83 & 1.06 & 0.84 & 0.84 & 1.50 & 1.95 & -0.90 \\
\hline \multirow[t]{2}{*}{ Total } & 4.14 & 6.09 & 6.02 & 8.38 & 6.60 & 7.60 & -5.95 \\
\hline & \multicolumn{7}{|c|}{ Manufacturing } \\
\hline Within & 5.60 & 8.07 & 6.14 & 8.71 & 4.41 & 5.89 & -5.73 \\
\hline Between & 0.69 & 1.08 & 0.67 & 0.64 & 1.21 & 1.64 & -0.46 \\
\hline \multirow[t]{2}{*}{ Total } & 6.29 & 9.15 & 6.81 & 9.36 & 5.62 & 7.53 & -6.19 \\
\hline & \multicolumn{7}{|c|}{ Market services } \\
\hline Within & 1.57 & 2.64 & 0.37 & 1.57 & 2.49 & 5.33 & -4.69 \\
\hline Between & 0.40 & 0.43 & 1.39 & 1.35 & 1.65 & 2.29 & 0.00 \\
\hline Total & 1.97 & 3.07 & 1.76 & 2.92 & 4.14 & 7.63 & -4.69 \\
\hline
\end{tabular}

Source: our calculations on Eurostat data.

For Italy, the shift and share analysis seems to confirm an increase in international fragmentation for both the whole economy and the manufacturing sector. This rise is at least 
partly counterbalanced by a shift towards less internationally-integrated industries. For Germany, both components moved in the same direction, showing a clear increase in the level of outsourcing. Therefore, the different dynamics in the two countries can be partially explained by quite diverging changes in specialisation. At an aggregate level, the firms' propensity to use imported inputs grew within each sector in both countries; moreover, the shift in the economic structure towards more internationalised sectors was larger in Germany than in Italy. The two different dynamics of internationalisation and the quite diverging specialisation patterns could indicate a discrepancy in the "success rate" of outsourcing policies between the two countries. This holds true for the manufacturing sectors but even more for the two whole economies.

Our results are consistent with national accounts data: in Italy, the value added share of market services increased from $46.6 \%$ to $48.7 \%$ in $1995-2000$, and reached $50.1 \%$ in 2007 . Symmetrically, the value added share of the manufacturing sector decreased in the same period, albeit at a slower pace in the final period of analysis. The pattern observed in Germany is partly different: from 1995 to 2000, the value-added share of market services increased fairly sedately (from $44.4 \%$ to $45.7 \%$ ) before accelerating to a maximum of $47.4 \%$ in 2006, while in 2007 it declined to $47.1 \%$. In a context characterised by a sizeable reduction in the value-added share of the construction industry after the peak of the early 1990s driven by reunification, the relative weight of industry decreased from 1995 to 2003, inverting the trend in 2004-2007, and the value-added share of German industry returned to the levels of the early to mid-1990s: this macro evidence further attests to the good performance of German manufacturing firms from the middle years of the last decade.

\section{Conclusions}

The growth of international trade in intermediate goods reflects, at least in part, the firms' choice to relocate their production abroad to exploit cost-benefits related to labour or other production factors. In 2007, the final year of our analysis, the direct and indirect import content of the production of goods and services, which is our indicator of international outsourcing, was about $17 \%$ for both the Italian and the German economies (excluding energy products). The import content of exports was slightly higher in Italy than in Germany due to a different sectoral composition of exports, therefore, on this basis and from a static point of view, also Italy could be defined as a "bazaar economy".

In terms of solely the manufacturing sectors, our analysis implies that Italian firms are slightly more internationalised than German firms: in 2007, the direct and indirect import content of production amounted to $31.1 \%$ in Italy and $29.5 \%$ in Germany, despite the higher share of low-tech sectors in the former, which are apparently the least internationally fragmented.

Although both Italy and Germany show similar levels of internationalisation at the end of the analysis period, different dynamic patterns led to those levels. During the whole of the 12year period, German firms, which started from a lower level of internationalisation, spurred faster growth compared with the Italian firms. In addition, it is important to note that, this weaker pattern for Italy can be partly explained by a more pronounced structural shift of production towards the service sectors, which are far less internationalised than manufacturing. Moreover, while Italy experienced a slight acceleration in the second subperiod (2000-2007) ${ }^{22}$, in Germany the dynamics were more pronounced in 1995-2000 and, successively, after 2004. The pattern in the first period seems to be related to the crises suffered by the Italian lira and the Spanish peseta in 1992 and 1995, which hampered the price competitiveness of German products and triggered a significant change in the strategies of

\footnotetext{
${ }^{22}$ All the indicators used in the analysis produced evidence of this slight acceleration, i.e. ICP, DIICP, DIICE and IITI.
} 
German firms. After a stasis in 2001-2004, the internationalisation process of German firms regained momentum, also in response to the qualitative upgrading and/or increasing specialisation of Chinese exports in sectors of relevance to the German economy. ${ }^{23}$

As in the case for the whole economy, German manufacturing firms spurred faster growth from 1995 to 2007 according to almost all the indicators presented here, with the high-tech sectors fuelling the highest growth in international fragmentation. On the other hand, international fragmentation was significant in both the low and medium-tech industries in Italy. This structural change contributed to the positive performance of Germany's export market share in that period by boosting the price competitiveness of German goods.

Conversely, Italian firms spurred slower growth in the degree of internationalisation of production at least up to 2005, while the slight acceleration that can be observed in the average of the second sub-period is the result of stagnation in 2000-2004 and a substantial increase in 2005-2007 (figure 1). This seems to signal a strategic change and a reorganisation of production in Italian firms, or at least in a significant part of them. This hypothesis is fully consistent with the results of Brandolini and Bugamelli (2009), which explain the interruption of the fall of total factor productivity observed for the Italian economy in the middle years of the last decade with the firms' reorganisation of production processes. The new challenges posed by increased competition from low-wage countries (or more generally by globalisation), by the diffusion of information and communication technologies and by the adoption of the euro (which, among other things, put a stop to the competitive devaluations of the lira) induced the most dynamic Italian firms to rethink their organisation, including their degree of vertical specialisation.

While this transformation process was still under way, the world economy was hit by the major financial crisis of 2008-2009, however, according to the Banca d'Italia Survey of industrial and service firms, revenues fell more slowly at those firms that had significantly changed their strategies in the previous years. ${ }^{24}$ In fact these developments need to be analysed in future research.

Although the input-output tables for more recent years are not yet available, the levels and structures of the international division of labour for Germany and Italy produced by our analysis for 2007 are likely to be the same or at least similar to those observed at the beginning of the global crisis, which had a particularly negative impact on the international trade of intermediate goods. In fact, the multiplicative effect of the "global supply chain" helps to explaining the depth of the collapse in world trade during the crisis. ${ }^{25}$ However, in its aftermath, the rate of international outsourcing could intensify due to the need of firms in the developed countries to both further increase their cost competitiveness and, presumably, establish new export platforms near or in the markets that are recovering from the crisis at a faster pace, such as China, India, the Far East and Brazil.

Appendix: Matrix algebra

In this section we present a more compact notation for the indices utilised in the paper by recasting them in matrix form.

For the IITI_broad index we use

IITI_broad $=u{ }_{m} A Y\left[u^{\prime}\left({ }_{m} A+{ }_{d} A\right) Y\right]^{-1}$

\footnotetext{
${ }^{23}$ Mannarino et al. (2008) find evidence of a strong qualitative upgrading in Chinese medium-high quality machinery exports in 1996-2006, even though German and Italian products remain positioned at higher quality levels. Looking at the whole manufacturing sector, Schott (2008) finds an increasing overlap of the exported product mix between China and the OECD countries during the 1972-2005 period, even though the quality gap (proxied by mean unit values differentials) between OECD and Chinese product varieties widened over time.

${ }^{24}$ See Banca d'Italia (2010, p. 112).

${ }^{25}$ See, for example, Bems et al. (2009) and Robertson (2009); but, for an almost opposite point of view, see also Altomonte and Ottaviano (2009).
} 
with each element ${ }_{m} a_{i j}$ of the $n$-dimensional square matrix ${ }_{m} A$ representing the imported inputs from industry $i$ utilised for the production of industry $j$, each element ${ }_{d} a_{i j}$ of the $n$ dimensional square matrix ${ }_{d} A$ representing the domestically produced input from industry $i$ for the production of industry $j, Y$ is the $n$-vector of gross output, $u$ is a $n x 1$ vector of 1 's and $n$ the number of industries.

The IITI_narrow index is calculated as

IITI_narrow $=u^{\prime}\left({ }_{m} A^{*} I\right) Y\left\{u^{\prime}\left[\left({ }_{m} A+{ }_{d} A\right)^{*} I\right] Y\right\}^{-1}$

where $\left({ }_{m} A^{*} I\right)$ is the diagonal import matrix ${ }_{m} A$ and $\left[\left({ }_{m} A+{ }_{d} A\right)^{*} I\right]$ the diagonal matrix of the total input matrix $\left({ }_{m} A+{ }_{d} A\right)$.

The expression for ICP index, as defined in [3], can be written as:

$I C P=u^{\prime}{ }_{m} A Y\left[u^{\prime} Y\right]^{-1}$

where each element ${ }_{m} a_{i j}$ of the $n$-dimensional square matrix ${ }_{m} A$ represents the imported inputs from industry $i$ utilised for the production of industry $j, Y$ is the $n$-vector of gross output, $u$ is a $n x 1$ vector of 1 's and $n$ the number of industries.

The expression for DIICP index, as defined in [4], is a bit more complicated since it includes the inverse of the Leontief matrix, $\left(I-{ }_{d} A\right)^{-1}$, which allows us to capture the imported inputs embodied in the domestic output:

$D I I C P=\left[u^{\prime}{ }_{m} A\left(I-{ }_{d} A\right)^{-1} Y\right]\left[u^{\prime} Y\right]^{-1}$

with each element ${ }_{d} a_{i j}$ of the $n$-dimesional square matrix ${ }_{d} A$ representing the domestically produced input from industry $i$ for the production of industry $j$ and $I$ is a $n x n$ identity matrix.

The matrix notation for the ICE and the DIICE indices, as defined in [5] and in [6], are then:

$I C E=u^{\prime}{ }_{m} A Y\left[u^{\prime} X\right]^{-1}$

and

$D I I C E=\left[u^{\prime}{ }_{m} A\left(I-{ }_{d} A\right)^{-1} Y\right]\left[u^{\prime} X\right]^{-1}$

where $X$ is the $n$-vector of exports.

Finally, the matrix notation for the VAP index, as defined in [6], is:

$I C P=u^{\prime} V\left[u^{\prime} V\right]^{-1}$

with $V$ as the $n$-vector of value added.

Altomonte C. and Ottaviano G.I.P. (2009). Resilient to the crisis? Global supply chains and trade flows, in R. Baldwin (ed.) The Great Trade Collapse, VOX - CEPR.

Amiti M. and Wei S.-J. (2005a). Service Outsourcing, Productivity and Employment, IMF working paper 238.

Amiti M. and Wei S.-J. (2005b). Fear of Outsourcing: Is It Justified?, Economic Policy, April: 308-348.

Anderton R. (1999). Innovation, product quality, variety, and trade performance: an empirical analysis of Germany and the UK, Oxford Economic Papers 51: 152-167.

Baldwin R. and Venables A.J. (2010). Relocating the value chain: off-shoring and agglomeration in the global economy, paper presented at the European Research Workshop in International Trade, Rome, June 2010.

Banca d'Italia (2010). Relazione annuale sul 2009, Rome.

Barba Navaretti G. and Castellani D. (2004). Investments Abroad and Performance at Home: Evidence from Italian Multinationals, CEPR Working Paper 4284.

Belke A., Mattes A. and Wang L. (2007). The bazaar economy hypothesis revisited. A new measure for Germany's international openness, Hohenheimer Diskussionbeiträge 285.

Bems R., Johnson R.C. and Yi K.-M. (2009). The collapse of global trade: Update on the role of global linkages, in R. Baldwin (ed.) The Great Trade Collapse, VOX - CEPR.

Bracci L. (2006). Una misura della localizzazione internazionale, in ICE Rapporto sul commercio estero, Rome. 
Brandolini A. and Bugamelli M. (ed.) (2009). Rapporto sulle tendenze nel sistema produttivo italiano, Questioni di economia e finanza 45, Banca d'Italia.

Breda E., Cappariello R. and Zizza R. (2009). Vertical specialisation in Europe: Evidence from the import content of exports, in L. Lambertini (ed.) Firms' Objectives and Internal Organisation in a Global Economy: Positive and Normative Analysis, Palgrave MacMillan.

Bugamelli M., Cingano F., D’Aurizio L. and Lagna F. (2008). Il sistema produttivo italiano: creative destruction o plain destruction?, Banca d'Italia, mimeo.

Chen H., Kondratowicz M. and Yi K.M. (2005). Vertical specialization and three facts about U.S. international trade, The North American Journal of Economics and Finance, 16, 35-59.

Danninger F. and Joutz S. (2007). What explains Germany's rebounding export market share?, IMF Working paper 07/24.

Daveri F. and Jona-Lasinio C. (2008). Off-shoring and productivity growth in the Italian manufacturing industry, CESifo Economic Studies 54, 3.

Diehl M. (1999). The Impact of International Outsourcing on the Skill Structure of Employment: Empirical Evidence from German Manufacturing Industries, Kiel working papers 946.

ECB (2005a). Import content of euro area exports, mimeo.

ECB (2005b). Measure of the export impulse to euro area growth: should we look at net trade or exports?, mimeo.

ECB (2005c). Competitiveness and the export performance of the euro area, Occasional paper series 30, June.

Egger H. and Egger P. (2003). On market concentration and international outsourcing, Applied Economics Quarterly, 49, 49-64.

Egger H. and Egger P. (2006). International Outsourcing and the Productivity of LowSkilled Labor in the EU, Economic Inquiry, Oxford University Press, 44(1), 98-108.

European Economic Advisory Group (2005). Outsourcing, in CESifo (ed.), Report on the European Economy, Chapter 2.

Eurostat (2008). Eurostat Manual of Supply, Use and Input-Output Tables, Methodologies and Working papers.

Falzoni A.M. and Tajoli L. (2007). Does outsourcing abroad intermediates and jobs affect the domestic labour market? The case of Italy, paper presented at the IX European Trade Study Group Conference, Athens, September 2007.

Feenstra R.C. (1998). Integration of Trade and Disintegration of Production in the Global Economy, Journal of Economic Perspectives, 12, 31-50.

Feenstra R.C. and Hanson G.H. (1996). Globalization, outsourcing, and wage inequality, AEA papers and proceedings, 86, 240-245.

Feenstra R.C. and Hanson G.H. (1999). The impact of outsourcing and high-technology capital on wages: estimates for the United States, 1979-1990, Quarterly Journal of Economics 114, 907-940.

Hummels D., Ishii J. and Yi K. (2001). The nature and growth of vertical specialization in world trade, Journal of International Economics, 54, 75-96.

Hummels D., Rapoport D. and Yi K. (1998). Vertical specialization and the changing nature of world trade, FRBNY Economic Policy Review, June, 79-98.

Istat (2006). Il nuovo sistema input-output, February, mimeo.

Jäckle R. (2006). The Impact of FDI on the Skill Structure in German Manufacturing, Applied Economics Quarterly, 52, Supplement.

Mannarino L., Pupo V., Ricotta F. and Succurro M. (2008). Export quality in the machinery sector: Some evidence from main competitors, MPRA paper 12677. 
Marin D. (2004). 'A Nation of Poets and Thinkers' - Less So with Eastern Enlargement? Austria and Germany, CEPR Discussion Paper 3526.

Marin D. (2006). A New International Division of Labor in Europe: Outsourcing and Offshoring to Eastern Europe, Journal of the European Economic Association, 4, 2-3, 612622.

OECD (2007). Staying competitive in the global economy: moving up the value chain.

Robertson R. (2009). Mexico and the great trade collapse, in R. Baldwin (ed.) The Great Trade Collapse, VOX - CEPR.

Schott P.K. (2008). The relative sophistication of Chinese exports, Economic Policy, 23, 549.

Sinn H.W. (2003). Bazaar Economy, Ifo-Viewpoint, 50. 